Integrin-ligand binding properties govern cell migration speed through cell-substratum adhesiveness

Sean P. Palecek, Joseph C. Loftus, Mark H. Ginsberg, Douglas A. Lauffenburger \& Alan F. Horwitz

Nature 385, 537-540 (1997)

The triangle symbols in Figs 1a, 2a, 3a and 4a failed to reproduce satisfactorily: the complete figures are reprinted here.

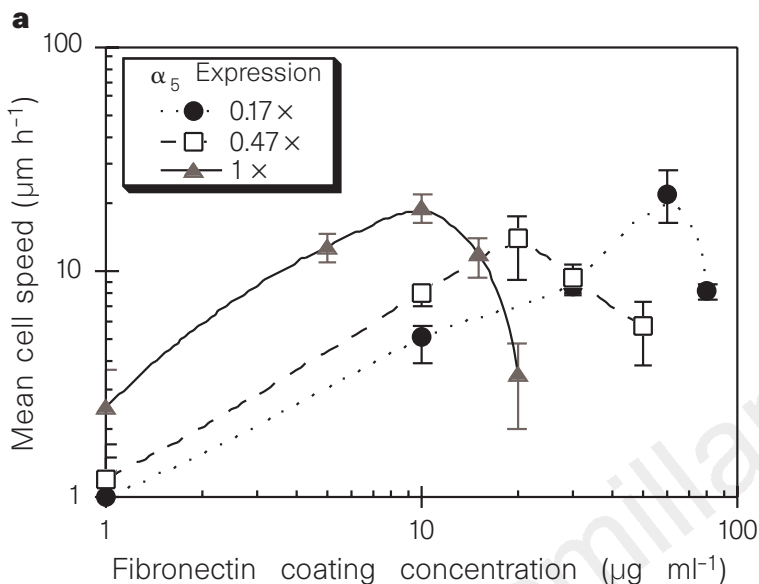

$2 a$

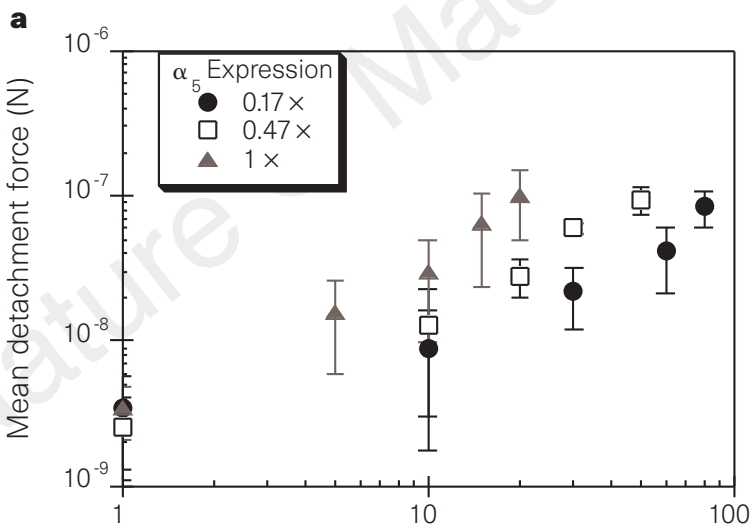

Fibronectin coating concentration $\left(\mu \mathrm{g} \mathrm{ml}^{-1}\right)$ 4a

\section{Total synthesis of the potential anticancer vaccine KH-1 adenocarcinoma antigen}

Prashant P. Deshpande \& Samuel J. Danishefsky

Nature 387, 164-166 (1997)

In Figs 1 and 2, various hydroxyl groups were incompletely represented. The corrected figures are shown here (Fig. 1, top; Fig. 2, bottom).

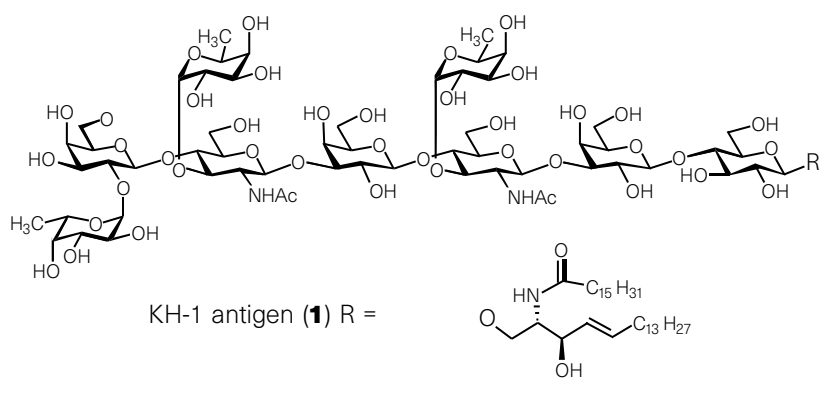

Bioconjugatable analogue (2) $R=$ 3a

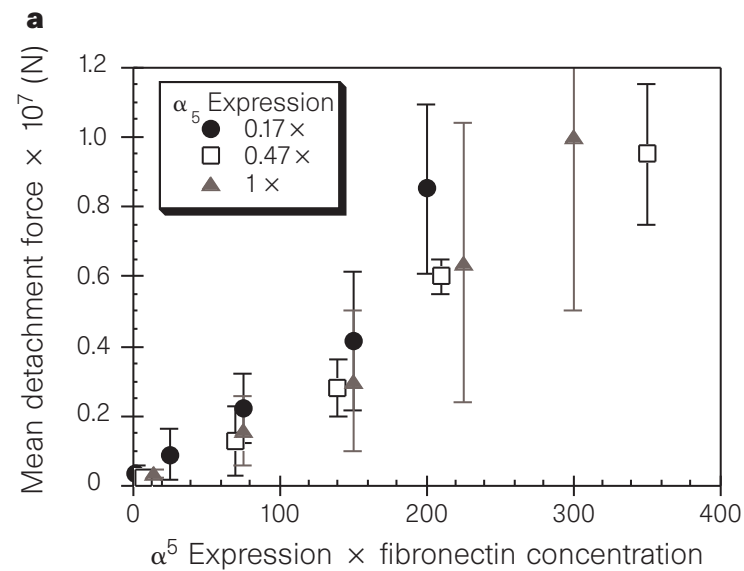

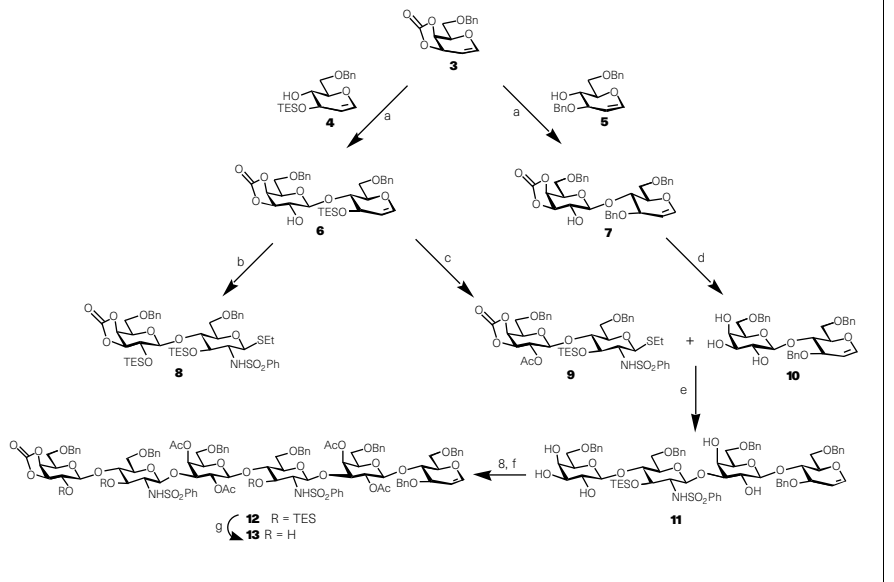




\section{Integrin-ligand binding} properties govern cell migration speed through cellsubstratum adhesiveness

\section{Sean P. Palecek ${ }^{\star}$, Joseph C. Loftus $\dagger$, Mark H. Ginsberg $\dagger$,} Douglas A. Lauffenburger ${ }^{\star}$ \& Alan F. Horwitz $\ddagger$

${ }^{*}$ Department of Chemical Engineering and Center for Biomedical Engineering, Massachusetts Institute of Technology, Cambridge, Massachusetts 02139, USA $\dagger$ Department of Vascular Biology, The Scripps Research Institute, La Jolla, California 92037, USA

$\ddagger$ Department of Cell and Structural Biology, University of Illinois, Urbana, Illinois 61801, USA

Migration of cells in higher organisms is mediated by adhesion receptors, such as integrins, that link the cell to extracellularmatrix ligands, transmitting forces and signals necessary for locomotion $^{1-4}$. Whether cells will migrate or not on a given substratum, and also their speed, depends on several variables related to integrin-ligand interactions, including ligand levels ${ }^{5,6}$, integrin levels ${ }^{7-9}$, and integrin-ligand binding affinities ${ }^{10-12}$. These and other ${ }^{13}$ factors affect the way molecular systems integrate to effect and regulate cell migration. Here we show that changes in cell migration speed resulting from three separate variables - substratum ligand level, cell integrin expression level, and integrin-ligand binding affinity-are all quantitatively predictable through the changes they cause in a single unifying parameter: short-term cell-substratum adhesion strength. This finding is consistent with predictions of a mathematical model for cell migration ${ }^{14}$. The ligand concentration promoting maximum migration speed decreases reciprocally as integrin expression increases. Increases in integrin-ligand affinity similarly result in maximal migration at reciprocally lower ligand concentrations. The maximum speed attainable, however, remains unchanged as ligand concentration, integrin expression, or integrin-ligand affinity vary, suggesting that integrin coupling with intracellular motors remains unaltered.

Maximal cell migration speed is predicted to occur at an intermediate ratio of cell-substratum adhesiveness to intracellular contractile force, at which the cell can form new attachments at the cell front but break attachments at the rear ${ }^{6,14}$. We therefore measured cell migration speed and short-term cell-substratum adhesiveness for different substratum ligand levels, integrin expression levels, and integrin-ligand binding affinities. This allowed us to test quantitatively the prediction that effects of changes in these molecular properties on cell migration speed can be predicted on the basis of their influence on short-term adhesiveness. Our short-term adhesion assay quantifies dynamic interactions between cell receptors and substratum ligands in a manner representative of events at the front and rear of migrating cells ${ }^{15,16}$.

To vary receptor expression we transfected $\alpha_{5}$-deficient CHO B2 cells $^{7}$ with a human $\alpha_{5}$ cDNA, and sorted expressors by flow cytometry into populations with different relative expression levels of $\alpha_{5} \beta_{1}$ fibronectin receptors. To vary integrin affinity state we used $\mathrm{CHO}$ cells transfected with the $\alpha_{\text {IIb }} \beta_{3}\left(K_{\mathrm{a}}<1.4\right.$ $\left.\times 10^{4} \mathrm{M}^{-1}\right)$ fibrinogen receptor and $\alpha_{\mathrm{IIb}} \beta_{3}\left(\beta_{1-2}\right)\left(K_{\mathrm{a}}=4.85\right.$ $\left.\pm 0.84 \times 10^{6} \mathrm{M}^{-1}\right)$, a higher-affinity extracellular-domain mutation with 6 amino acids of the $\beta_{3}$ ligand-binding domain replaced with sequences derived from $\beta_{1}$ (ref. 17). Both $\alpha_{\text {IIb }} \beta_{3}$ and $\alpha_{\text {IIb }} \beta_{3}\left(\beta_{1-2}\right)$ can be activated to higher affinity states by incubation with anti-LIBS2 antibody $\left(\alpha_{\mathrm{IIb}} \beta_{3}, K_{\mathrm{a}}=1.66 \pm 0.33 \times 10^{7} \mathrm{M}^{-1}\right.$; $\alpha_{\text {IIb }} \beta_{3}\left(\beta_{1-2}\right), K_{\mathrm{a}}=4.55 \pm 0.77 \times 10^{7} \mathrm{M}^{-1}$ ) (ref. 18). Mean CHO a
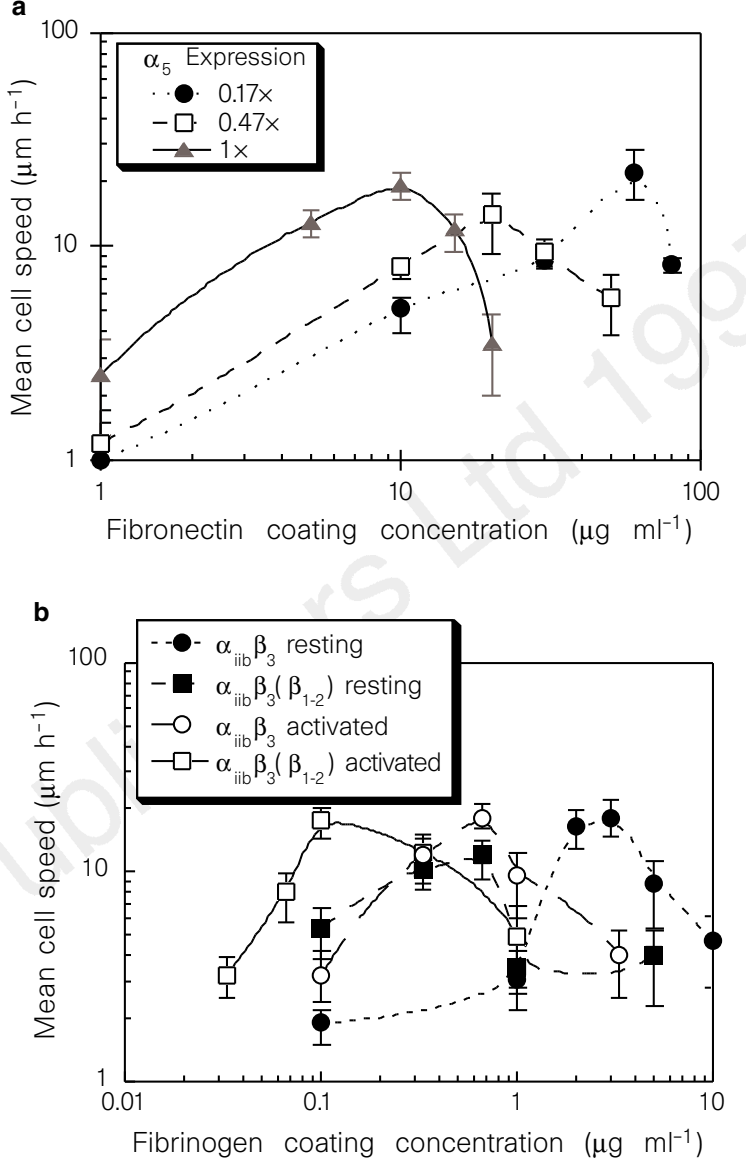

Figure 1 The speed of cell migration depends on substrate extracellular-matrix concentration, integrin expression level, and integrin-ligand affinity. Mean cell migration speed is determined using image analysis to track centroids of $\mathrm{CHO}$ cells with different integrin expression (a) and integrin-ligand affinity (b). Receptor expression was varied by transfecting $\alpha_{5}$-deficient $\mathrm{CHO}$ B2 cells with human $\alpha_{5}$ and sorting populations with different expression. Integrin-ligand affinity was varied by transfecting $\mathrm{CHO}$ cells with $\alpha_{\| \mathrm{lb}} \beta_{3}$ and $\alpha_{\| \mathrm{lb}} \beta_{3}\left(\beta_{1-2}\right)$, a higher-affinity mutant. These integrins were also activated by incubation with monoclonal antibody 62 (anti-LIBS2 antibody). Error bars represent 95\% confidence intervals on the mean cell speed. CHO-cell populations with different integrin expression (a) or integrin-ligand affinity (b) all have a biphasic migration-speed dependence on fibronectin concentration. As $\alpha_{5}$ expression (a) or $\alpha_{\| b} \beta_{3}$-fibrinogen affinity increases (b), the extracellular-matrix concentration promoting maximal migration decreases; at low concentrations, migration speed increases as expression or affinity increases, whereas at high concentrations, migration speed decreases as expression or affinity increases. Maximum attainable migration speed is not a function of integrin expression or affinity.

cell migration speed, measured by time-lapse video-microscopy, exhibits a biphasic dependence on extracellular-matrix ligand concentration regardless of integrin expression level (the $\alpha_{5} \beta_{1}$ receptor on fibronectin; Fig. 1a) or integrin-ligand binding affinity (the $\alpha_{\mathrm{IIb}} \beta_{3}$ receptor on fibrinogen; Fig. $1 \mathrm{~b}$ ). The maximum attainable cell speed remains the same in all cases; only the position of the biphasic curve is shifted. At low ligand concentrations, cell speed increases as integrin expression or binding affinity increases, whereas at high ligand concentrations, cell speed increases as integrin expression or binding affinity decreases. At intermediate ligand concentrations, intermediate integrin expression levels and intermediate bindingaffinity states result in greatest cell speed. At maximum migration speeds $\left(10-20 \mu \mathrm{mh}^{-1}\right), \mathrm{CHO}$ cells are moderately spread and move by extending multiple lamellae in different directions. Some 

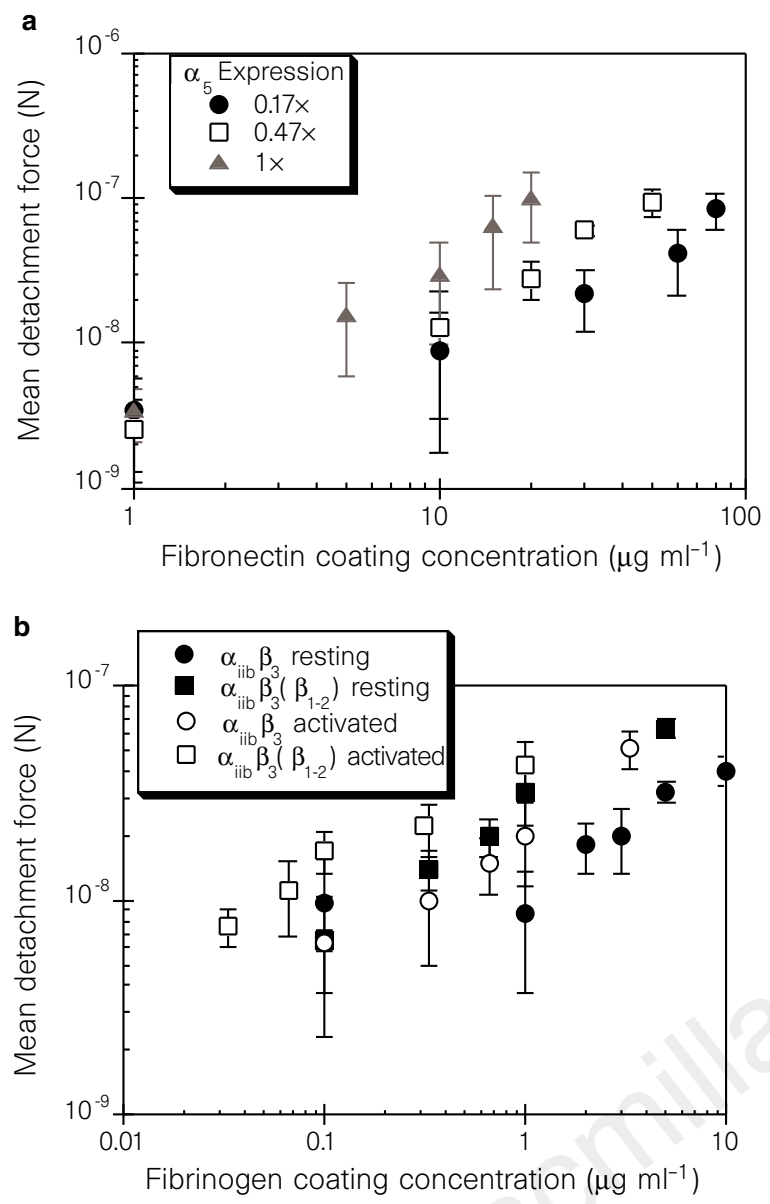

Figure 2 Cell-substratum adhesiveness increases as extracellular-matrix concentration, integrin expression, and integrin-ligand affinity increase. Shortterm mean cell detachment force, measured by shear-flow detachment, was measured for $\mathrm{CHO}$ cells with different levels of integrin expression and integrinligand affinity. Receptor expression was varied by transfecting $\alpha_{5}$-deficient $\mathrm{CHO}$ B2 cells with human $\alpha_{5}$ and sorting populations with different expression levels. Integrin-ligand affinity was varied by transfecting $\mathrm{CHO}$ cells with $\alpha_{\| b} \beta_{3}$ and $\alpha_{\| b} \beta_{3}\left(\beta_{1-2}\right)$, a higher-affinity mutant. These integrins were also activated by incubation with monoclonal antibody 62 (anti-Libs2 antibody). Error bars represent $95 \%$ confidence intervals on the mean detachment force. In each cell population the mean detachment force increases with the extracellular-matrix concentration. At every concentration, the mean detachment force increases as integrin expression (a) or integrin-ligand affinity (b) increases.

lamellae are stable and move the cell in the direction of their extensions, but other lamellae retract. At ligand concentrations lower than that giving rise to the maximum speed, the cells are more rounded but still extend lamellae, which are smaller and shorter lived than lamellae in migrating cells; these unstable lamellae cannot move the cell body. At ligand concentrations higher than that giving rise to the maximum speed, the cells are very spread and extend lamellae in a manner similar to migrating cells; the cell body does not move well, presumably because it cannot release adhesions to the substrate.

Short-term mean cell detachment force, measured by a shearflow detachment assay ${ }^{19}$ after a 20 -min incubation, increases with ligand concentration at each integrin expression level or affinity state (Fig. 2). At any ligand concentration, mean detachment force a

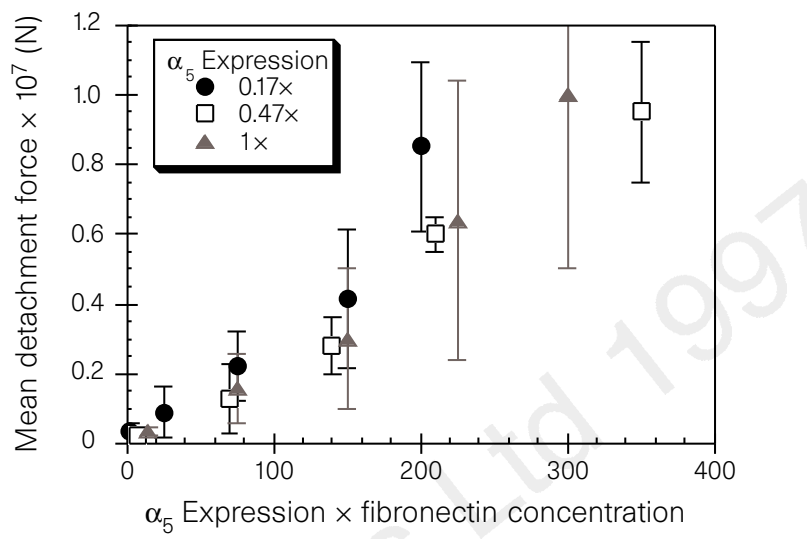

b

Relative $\alpha_{5}$ expression

Fibronectin concentration at maximum speed $\left.(\mu \mathrm{g} \mathrm{ml})^{-1}\right)$

Peak fibronectin concentration $\times \alpha_{5}$ expression

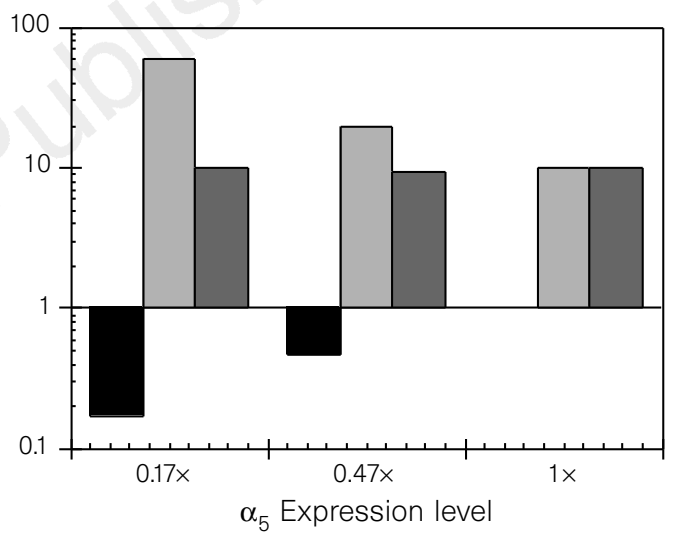

Figure 3 The number of cell-substratum bonds seems to determine cellsubstratum adhesiveness and migration speed. At constant receptor-ligand affinity, the number of cell-substratum bonds is approximately linearly proportional to the product of extracellular-matrix concentration and receptor expression. Mean cell detachment force increases linearly with this product at each expression level (a). Thus short-term cell-substratum adhesiveness appears to be a linear function of the number of cell-substratum bonds. The product of $\alpha_{5}$ expression and fibronectin concentration remains constant at the maximum migration speed (b), suggesting the existence of an optimal receptor occupancy at the maximum migration speed. 


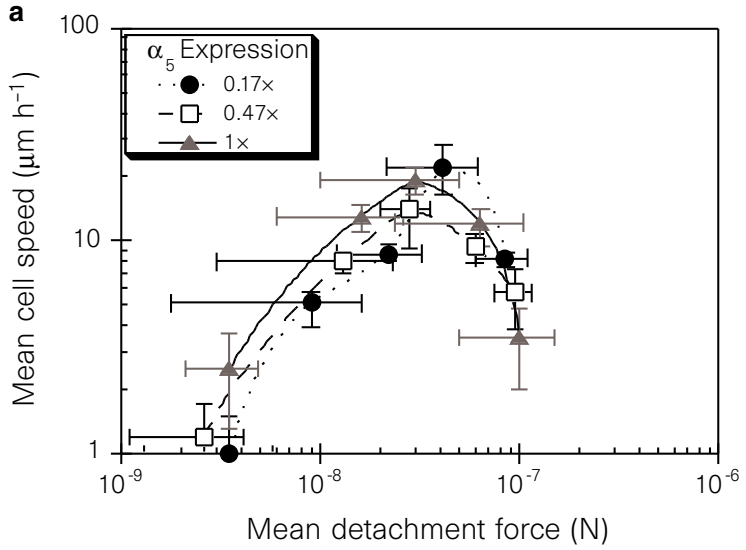

b

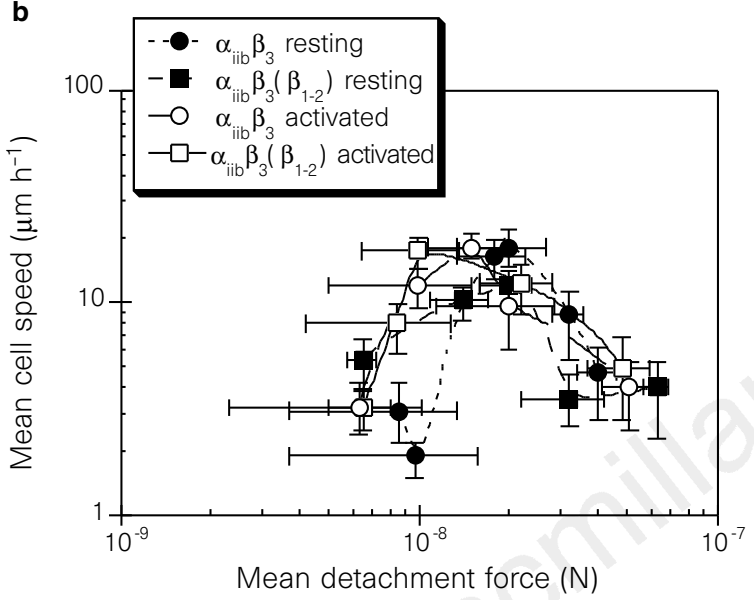

Figure 4 Cell migration speed (Fig. 1) correlates with cell-substratum adhesiveness (Fig. 2) as extracellular-matrix concentration, integrin expression, and integrin-ligand affinity change. Cell speed was measured by image analysis of cell centroids as a function of time, and detachment force was measured by shear-flow detachment. Error bars represent 95\% confidence intervals on the mean cell speed and detachment force. CHO B2 cells transfected with human $\alpha_{5}$ and sorted into populations with different relative $\alpha_{5}$ expression demonstrate that, as fibronectin substratum concentration or $\alpha_{5}$ expression change, the relationship between migration speed and mean detachment force is a constant, biphasic function (a). As $\alpha_{\| b} \beta_{3}$-fibrinogen affinity increases owing to the mutation from $\beta_{3}$ to $\beta_{3}\left(\beta_{1-2}\right)$ and to activation induced by monoclonal antibody 62 , the cell migration-speed dependence on short-term adhesiveness remains a constant, biphasic relationship (b). Maximum speed occurs at 2-4 $\times 10^{-8} \mathrm{~N}$ for both $\alpha_{5} \beta_{1-}$ and $\alpha_{\| b} \beta_{3}$-mediated migration, suggesting that these receptors can interact with the cytoskeleton and transmit intracellular motile forces similarly as extracellularmatrix concentration, integrin expression, and integrin-ligand affinity vary.

has the same linear relationship to the product of $\alpha_{5}$ expression and fibronectin concentration (Fig. 3a), suggesting that the short-term mean detachment force is proportional to the number of cellsubstratum bonds. (At high ligand concentrations there may be significant receptor depletion, yielding an asymptotic plateau in this plot.) The fibronectin concentration allowing maximum migration speed is inversely proportional to the $\alpha_{5}$ expression level, so that the product of the fibronectin concentration at maximum cell speed and the $\alpha_{5}$ expression level is constant over the range of $\alpha_{5}$ expression levels in this study (Fig. 3b). Because this product represents integrin-ligand bond number, it can be inferred that maximum migration occurs at an optimal, intermediate level of receptor occupancy.

To examine the relationship between migration speed and cell- substratum adhesiveness, we replotted cell migration speed as a function of detachment force (Fig. 4). Cell migration speed is a constant, biphasic function of cell-substratum adhesiveness as integrin expression or integrin-ligand binding affinity changes. The presence of an optimum adhesiveness for cell migration indicates that modulation of ligand concentration, integrin expression, and integrin affinity can be used to alter cell migration speed through changes in the short-term adhesive interaction between the cell and substratum. Relatively small changes in integrin expression or affinity can lead to substantial changes in migration speed. These variables seem to contribute quantitatively to short-term cell adhesion by altering the number of cell-substratum bonds. Both the $\alpha_{5} \beta_{1}$-fibronectin and the $\alpha_{\mathrm{IIb}} \beta_{3}$-fibrinogen bonds promote maximum cell speed at a cell-substratum detachment force of $2-4 \times 10^{-8} \mathrm{~N}$, suggesting that integrins with different ligandrecognition specificities can transmit intracellular motile forces similarly. Locomoting fibroblasts exert traction forces of about $20 \times 10^{-8} \mathrm{~N}$ (ref. 20). These detachment forces and traction forces are consistent with the mathematical model prediction that maximum cell speed occurs at an adhesiveness to contractile force ratio of $<1$ (ref. 14). High cell-substratum adhesiveness probably hinders cell migration by obstructing the release of adhesions at the rear of the cell ${ }^{12-23}$. Videotaped observations of cells at high adhesiveness reveal lamellipod extension and retraction, but little movement of the cell body. At low cell-substratum adhesiveness, however, inhibition of rear release is an unlikely explanation for reduced migration rates. Except at the lowest levels of adhesiveness, the cells are still able to extend lamellae, but these lamellae are smaller and less frequently extended that those in more adherent cells. Decreased rate of lamellipodal extension or more likely, decreased probability of formation of a stable attachment to the surface by the lamellae, probably account for the reduced migration at low adhesiveness ${ }^{24}$.

Additional variables such as lamellipodal extension, intracellular force generation, integrin clustering and avidity effects, and integrin signalling are important to the processes of cell adhesion and cell migration $^{4,12,13}$. For example, overexpression of FAK in CHO cells results in increased cell migration but does not alter cell spreading or adhesion, at least as measured in a particular assay ${ }^{25}$. Nonetheless, our results suggest that short-term cell-substratum adhesiveness is rate limiting in determining migration speed as the linkage between integrin and the extracellular matrix is altered, and can serve as a unifying parameter in understanding the influence of various molecular properties on migration speed.

This interrelation between migration and adhesiveness has important implications in clinical applications, such as various molecular therapeutic approaches to cancer ${ }^{26}$. Where decreased cell migration is generally desirable, targeting receptor expression or receptor-ligand binding affinity are potentially effective strategies. In biomaterials and tissue-engineering applications, increased migration is often desired ${ }^{27}$. Altering the extracellular-matrix ligand concentration seems to be the easiest means of affecting cell-substratum adhesiveness, but other approaches to change receptor number or receptor-ligand binding affinity, such as soluble binding competitors or drugs affecting receptor-ligand or receptor-cytoskeleton coupling, could allow additional control of cell adhesiveness and migration in a quantitatively predictable manner.

\section{Methods}

Cell preparation. CHO B2 cells ${ }^{7}$ were transfected with a human $\alpha_{5} \mathrm{cDNA}^{28}$ using lipofectamine (GIBCO-BRL), as described in the manufacturer's protocols. Generation of CHO cells expressing $\alpha_{\text {IIb }} \beta_{3}$ and $\alpha_{\text {IIb }} \beta_{3}\left(\beta_{1-2}\right)$ has been described $^{17}$. The cells were grown in DMEM containing 10\% FBS, $2 \mathrm{mM}$ glutamine, and $1 \%$ non-essential amino acids. The transfected cells were selected in DME containing $100 \mu \mathrm{g} \mathrm{ml}^{-1} \mathrm{G} 418$ and maintained in DME containing $50 \mu \mathrm{g} \mathrm{ml}^{-1} \mathrm{G} 418$. Cells expressing human $\alpha_{5}$ were selected 
from non-expressors by flow cytometry. Quantitative cell-surface expression of integrins was determined by flow cytometry ${ }^{29}$ using human $\alpha_{5}$ antibody 6F4 at 1:4 dilution of hybridoma supernatant to assay $\alpha_{5}$ expression and non-inhibitory $\alpha_{\mathrm{II}} \beta_{3}$ antibody D57 at 1:200 dilution of mouse ascites to assay $\alpha_{\mathrm{II}} \beta_{3}$ expression. Cells expressing $\alpha_{5}$ were sorted into three populations with different relative expression levels, and cells expressing $\alpha_{\mathrm{IIb}} \beta_{3}\left(\beta_{1-2}\right)$ were sorted into similar surface-expression profiles to $\alpha_{\mathrm{II}} \beta_{3}$ transfected cells. Both $\alpha_{\mathrm{II}} \beta_{3}$ and $\alpha_{\mathrm{II}} \beta_{3}\left(\beta_{1-2}\right)$ were activated to the highaffinity state by incubation with $100 \mu \mathrm{g} \mathrm{ml}^{-1}$ monoclonal antibody 62 (anti-LIBS2 antibody).

Adhesion assay. $\mathrm{CHO}$ cells were incubated on silaned fibrinogen- or fibronectin (Sigma)-coated glass slides for $20 \mathrm{~min}$ in serum-free OptiMEM 1 (GIBCO-BRL). The slide was placed in a shear-stress flow chamber ${ }^{19}$, which produces a linear gradient in shear with position along the centre line: $\tau_{w}=\left(6 \mu Q / h^{2} w_{1}\right) /(1-(z / L))$ where $\tau_{w}$ is the surface shear stress, $\nu$ the fluid viscosity, $Q$ the flow rate, $h$ the channel height, $w_{1}$ the channel width at the origin of the flow field, $z$ the distance from the origin along the centre line, and $L$ the length of the flow field. PBS with $\mathrm{Ca}^{2+}$ and $\mathrm{Mg}^{2+}$, heated to $37^{\circ} \mathrm{C}$, flowed through the chamber for $5 \mathrm{~min}$ to detach the cells. Cells in 20 fields along the slide were counted before and after flow detachment. Shear stress was calculated for each field and converted to shear force $\left(F_{\mathrm{s}}\right)$ by approximating cell morphology as a hemispherical cap, such that $F_{\mathrm{s}}=2.15 \pi\left(r_{\mathrm{p}}^{2}+h^{2}\right) \tau_{w}$ where $r_{\mathrm{p}}$ is the hemispherical cap radius and $h$ the height. The fraction of cells detached as a function of shear force was fit to the integrals of logarithmic normal probability density-function distributions to determine the mean shear force for detachment of $50 \%$ of the cells. Five detachment assays were performed for each cell type at each extracellular-matrix concentration, and mean detachment forces were averaged.

Migration assay. $\mathrm{CHO}$ cells were incubated on silaned, fibrinogen- or fibronectin-coated coverslips for $3 \mathrm{~h}$ in serum-free OptiMEM 1. Real-time digital image processing was used to acquire images and calculate cell centroid position as a function of time. The image-processing software (Engineering Technology Center, Mystic, CT) identifies cell boundaries from phase-contrast images and measures cell centroid position. We scanned 5-10 cells per field in 10 different fields every $15 \mathrm{~min}$ for $12 \mathrm{~h}$. The mean-squared displacement of the cell centroid as a function of time was calculated for each cell using nonoverlapping time intervals. The mean-squared displacements were averaged and fit to a persistent random walk mode ${ }^{30}$ to calculate cell speed, $S$, and persistence time, $P:\left\langle\mathrm{d}^{2}(t)\right\rangle=2 S^{2} P\left[t-P\left(1-\mathrm{e}^{-t / P}\right)\right]$.

Received 13 November; accepted 19 December 1996

1. Hynes, R. O. Cell 69, 11-25 (1992).

2. Cheresh, D. A. Adv. Mol. Cell Biol. 6, 225-252 (1993).

3. Schwartz, M. A. Schaller, M. D. \& Ginsberg, M. H. Annu. Rev. Cell Dev. Biol. 11, 549-599 (1995).

4. Lauffenburger, D. A. \& Horwitz, A. F. Cell 84, 359-369 (1996).

5. Goodman, S. L., Risse, G. \& van der Mark, K. J. Cell Biol. 109, 799-809 (1989)

6. DiMilla, P. A., Stone, J. A., Quinn, J. A., Albelda, S. A. \& Lauffenburger, D. A. J. Cell Biol. 122, 729-737 (1993).

7. Bauer, J. S, Schreiner, C. L., Giancotti, F. G., Ruoslahti, E \& Juliano, R. L. J. Cell Biol. 116, 477-487 (1992).

8. Giancotti, F. G. \& Ruoslahti, E. Cell 60, 849-859 (1990).

9. Keely, P. J., Fong, A. M., Zutter, M. M. \& Santoro, S. A. J. Cell Sci. 108, 595-607 (1995).

10. Duband, J.-L., Dufour, S., Yamada, S. S., Yamada, K. M. \& Thiery, J. P. J. Cell Sci. 98, 517-532 (1991).

11. Kuijpers, T. W. et al. J. Exp. Med. 178, 279-284 (1993).

12. Huttenlocher, A., Ginsberg, M. H. \& Horwitz, A. F. J. Cell Biol. 134, 1551-1562 (1996).

13. Huttenlocher, A., Sandborg, R. R. \& Horwitz, A. F. Curr. Opin. Cell Biol. 7, 697-706.

14. DiMilla, P. A., Barbee, K. \& Lauffenburger, D. A. Biophys. J. 60, 15-37 (1991).

15. Regen, C. M. \& Horwitz, A. F. J. Cell Biol. 119, 1347-1359 (1992).

16. Palecek, S. P. Schmidt, C. E. Lauffenburger, D. A. \& Horwitz, A. F. J. Cell Sci. 109, 941-952 (1996).

17. Bajt, M. L., Loftus, J. C., Gawaz, M. P. \& Ginsberg, M. H. J. Biol. Chem. 267, 22211-22216 (1992).

18. Frelinger, A. L., Du, X., Plow, E. F. \& Ginsberg, M. H. J. Biol. Chem. 266, 17106-17111 (1991).

19. Powers, M. J., Rodriguez, R. E. \& Griffith, L. G. Biotechnol. Bioeng. (in the press).

20. Oliver, T. N., Lee, J. \& Jacobson, K. Semin. Cell Biol. 5, 139-147 (1994).

21. Abercrombie, M., Heaysman, J. E. M. \& Pegrun, S. M. Exp. Cell Res. 59, 393-398 (1970).

22. Marks, P. W., Hendey, B. \& Maxfield, F. R. J. Cell Biol. 112, 149-158 (1991).

23. Jay, P. Y., Pham, P. A., Wong, S. A. \& Elson, E. L. J. Cell Sci. 108, 387-393 (1995).

24. Wessels, D., Vawter-Hugart, H., Murray, J. \& Soll, D. R. Cell Motil. Cytoskeleton 27, 1-12 (1994).

25. Cary, L. A., Chang, J. F \& Guan, J. J. Cell Sci. 109, 1787-1794 (1996).

26. Varner, J. A. \& Cheresh, D. A. Curr. Opin. Cell Biol. 8, 724-730 (1996).

27. Langer, R. \& Vacanti, J. Science 260, 920-926 (1993).

28. Argraves, W. S. et al. J. Cell Biol. 105, 1183-1190 (1987).

29. Loftus, J. C. et al. Science 249, 915-918 (1990).

30. Dunn, G. A. Agents Actions (suppl.) 22, 14-33 (1983)

Acknowledgements. We thank R. Isberg for 6F4 antibody, L. Reichardt for $\alpha_{\mathrm{s}} \mathrm{cDNA}$, and R. Juliano for CHO B2 cells. This work was supported by grants from the NIH to D.A.L., A.F.H., J.C.L. and M.H.G., and a Whitaker Foundation graduate fellowship in Biomedical Engineering to S.P.P.

Correspondence and requests for materials should be addressed to D.A.L. (e-mail: lauffen@mit.edu).

\section{MAP3K-related kinase involved in NF- $\kappa$ B induction by TNF, CD95 and IL-1}

\author{
Nikolai L. Malinin, Mark P. Boldin, Andrei V. Kovalenko \& \\ David Wallach
}

Department of Membrane Research and Biophysics, The Weizmann Institue of Science, 76100 Rehovot, Israel

Several members of the tumour-necrosis/nerve-growth factor (TNF/NGF) receptor family activate the transcription factor NF$\kappa B$ through a common adaptor protein, Traf2 (refs 1-5), whereas the interleukin 1 type-I receptor activates NF- $\mathrm{B}$ independently of Traf2 (ref. 4). We have now cloned a new protein kinase, NIK, which binds to Traf 2 and stimulates NF- $\kappa B$ activity. This kinase shares sequence similarity with several MAPKK kinases. Expression in cells of kinase-deficient NIK mutants fails to stimulate NF$\kappa B$ and blocks its induction by TNF, by either of the two TNF receptors or by the receptor CD95 (Fas/Apo-1), and by TRADD, RIP and MORT1/FADD, which are adaptor proteins that bind to these receptors. It also blocked NF- $\kappa \mathrm{B}$ induction by interleukin-1. Our findings indicate that NIK participates in an NFsignalling cascade common to receptors of the TNF/NGF family and to the interleukin-1 type-I receptor.

NF- $\kappa \mathrm{B}$, a ubiquitously expressed transcription factor comprising a homo- or heterodimer of DNA-binding proteins related to the proto-oncogene c-Rel, controls the expression of many immuneand inflammatory-response genes. In most cells NF- $\kappa \mathrm{B}$ exists in a

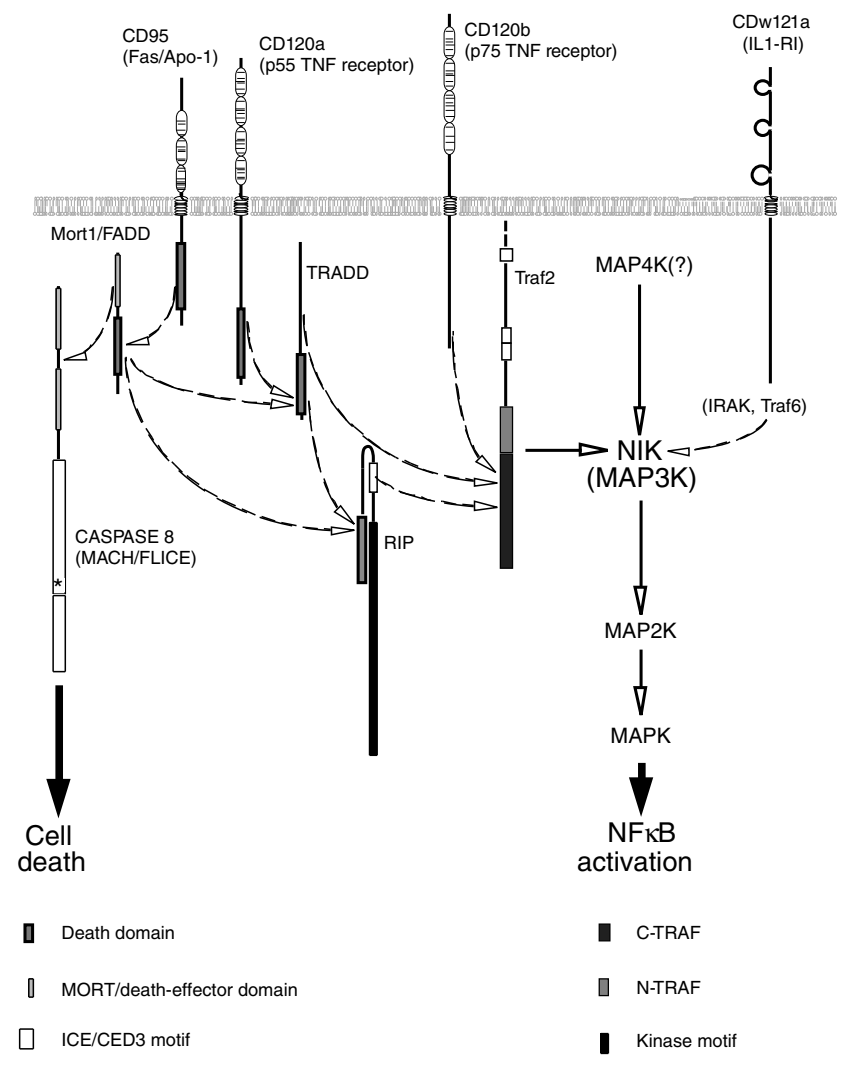

Figure 1 The known protein-protein interactions through which the TNF receptors (p55, or CD120a, and p75, or CD120b), CD95 (Fas/Apo-1) and CDw121a (the IL-1 type-I receptor) might affect the activity of NIK. 
Integrin-ligand binding properties govern cell migration speed through cell-substratum adhesiveness

Sean P. Palecek, Joseph C. Loftus, Mark H. Ginsberg, Douglas A. Lauffenburger \& Alan F. Horwitz

Nature 385, 537-540 (1997)

The triangle symbols in Figs 1a, 2a, 3a and 4a failed to reproduce satisfactorily: the complete figures are reprinted here.

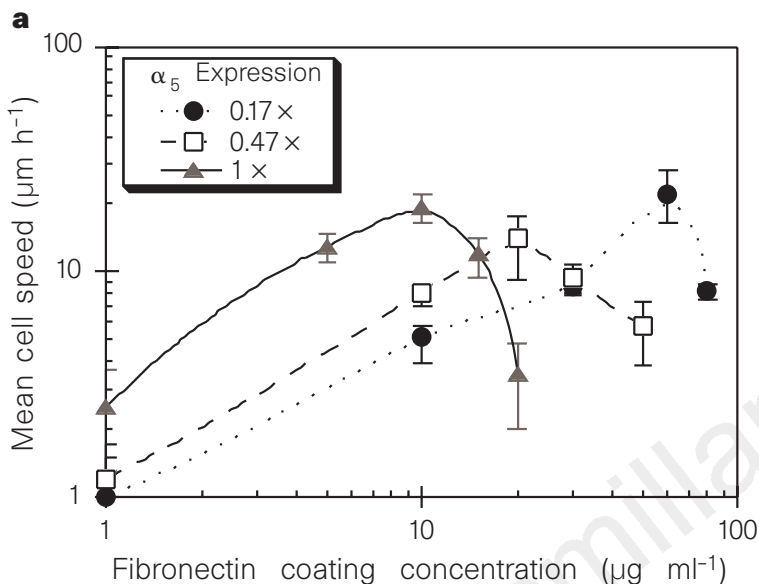

$2 a$

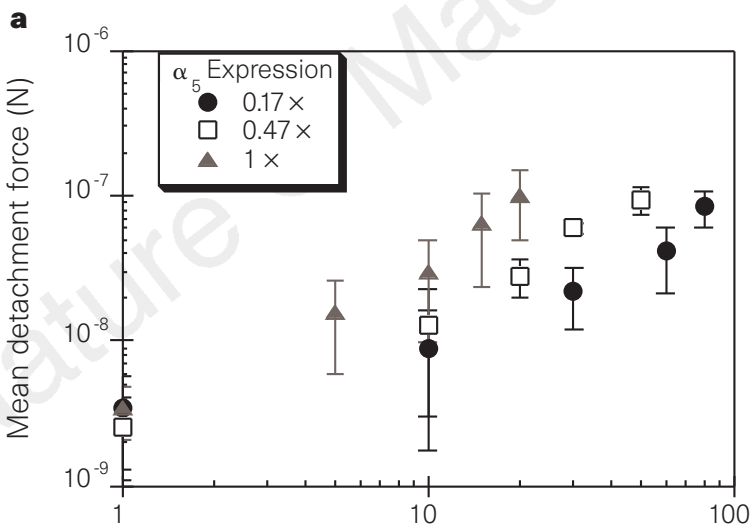

Fibronectin coating concentration $\left(\mu \mathrm{g} \mathrm{ml}^{-1}\right)$ 4a

\section{Total synthesis of the potential anticancer vaccine KH-1 adenocarcinoma antigen}

Prashant P. Deshpande \& Samuel J. Danishefsky

Nature 387, 164-166 (1997)

In Figs 1 and 2, various hydroxyl groups were incompletely represented. The corrected figures are shown here (Fig. 1, top; Fig. 2, bottom).

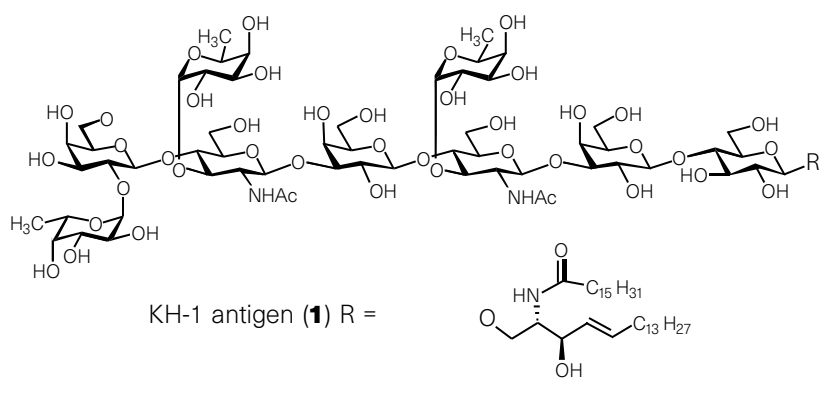

Bioconjugatable analogue (2) $R=$ 3a

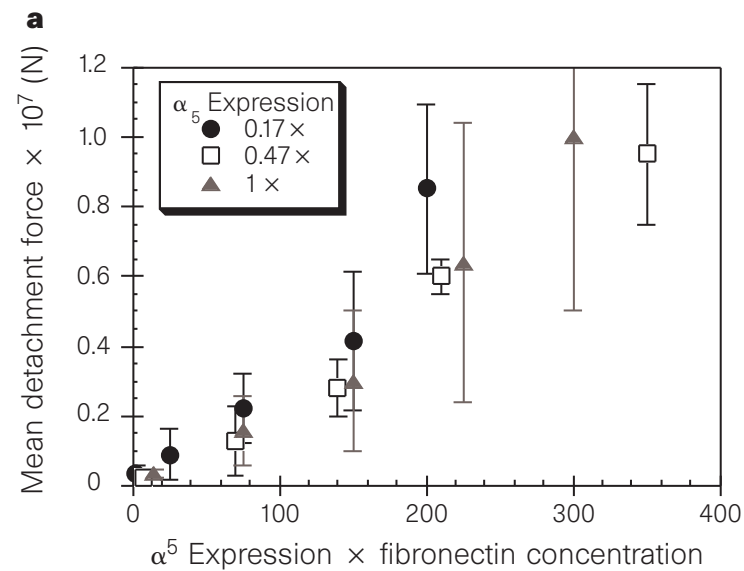

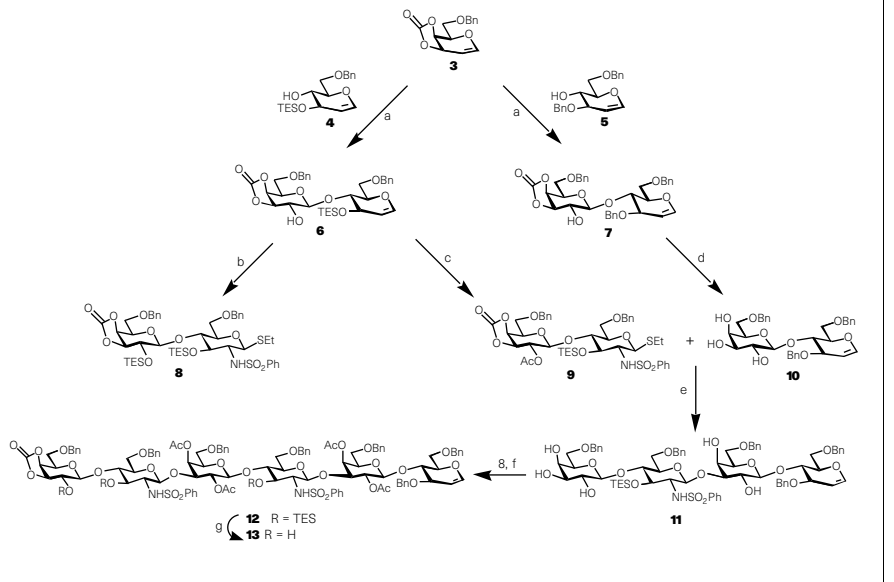




\section{Integrin-ligand binding} properties govern cell migration speed through cellsubstratum adhesiveness

\section{Sean P. Palecek ${ }^{\star}$, Joseph C. Loftus $\dagger$, Mark H. Ginsberg $\dagger$,} Douglas A. Lauffenburger ${ }^{\star}$ \& Alan F. Horwitz $\ddagger$

${ }^{*}$ Department of Chemical Engineering and Center for Biomedical Engineering, Massachusetts Institute of Technology, Cambridge, Massachusetts 02139, USA $\dagger$ Department of Vascular Biology, The Scripps Research Institute, La Jolla, California 92037, USA

$\ddagger$ Department of Cell and Structural Biology, University of Illinois, Urbana, Illinois 61801, USA

Migration of cells in higher organisms is mediated by adhesion receptors, such as integrins, that link the cell to extracellularmatrix ligands, transmitting forces and signals necessary for locomotion $^{1-4}$. Whether cells will migrate or not on a given substratum, and also their speed, depends on several variables related to integrin-ligand interactions, including ligand levels ${ }^{5,6}$, integrin levels ${ }^{7-9}$, and integrin-ligand binding affinities ${ }^{10-12}$. These and other ${ }^{13}$ factors affect the way molecular systems integrate to effect and regulate cell migration. Here we show that changes in cell migration speed resulting from three separate variables - substratum ligand level, cell integrin expression level, and integrin-ligand binding affinity-are all quantitatively predictable through the changes they cause in a single unifying parameter: short-term cell-substratum adhesion strength. This finding is consistent with predictions of a mathematical model for cell migration ${ }^{14}$. The ligand concentration promoting maximum migration speed decreases reciprocally as integrin expression increases. Increases in integrin-ligand affinity similarly result in maximal migration at reciprocally lower ligand concentrations. The maximum speed attainable, however, remains unchanged as ligand concentration, integrin expression, or integrin-ligand affinity vary, suggesting that integrin coupling with intracellular motors remains unaltered.

Maximal cell migration speed is predicted to occur at an intermediate ratio of cell-substratum adhesiveness to intracellular contractile force, at which the cell can form new attachments at the cell front but break attachments at the rear ${ }^{6,14}$. We therefore measured cell migration speed and short-term cell-substratum adhesiveness for different substratum ligand levels, integrin expression levels, and integrin-ligand binding affinities. This allowed us to test quantitatively the prediction that effects of changes in these molecular properties on cell migration speed can be predicted on the basis of their influence on short-term adhesiveness. Our short-term adhesion assay quantifies dynamic interactions between cell receptors and substratum ligands in a manner representative of events at the front and rear of migrating cells ${ }^{15,16}$.

To vary receptor expression we transfected $\alpha_{5}$-deficient CHO B2 cells $^{7}$ with a human $\alpha_{5}$ cDNA, and sorted expressors by flow cytometry into populations with different relative expression levels of $\alpha_{5} \beta_{1}$ fibronectin receptors. To vary integrin affinity state we used $\mathrm{CHO}$ cells transfected with the $\alpha_{\text {IIb }} \beta_{3}\left(K_{\mathrm{a}}<1.4\right.$ $\left.\times 10^{4} \mathrm{M}^{-1}\right)$ fibrinogen receptor and $\alpha_{\mathrm{IIb}} \beta_{3}\left(\beta_{1-2}\right)\left(K_{\mathrm{a}}=4.85\right.$ $\left.\pm 0.84 \times 10^{6} \mathrm{M}^{-1}\right)$, a higher-affinity extracellular-domain mutation with 6 amino acids of the $\beta_{3}$ ligand-binding domain replaced with sequences derived from $\beta_{1}$ (ref. 17). Both $\alpha_{\text {IIb }} \beta_{3}$ and $\alpha_{\text {IIb }} \beta_{3}\left(\beta_{1-2}\right)$ can be activated to higher affinity states by incubation with anti-LIBS2 antibody $\left(\alpha_{\mathrm{IIb}} \beta_{3}, K_{\mathrm{a}}=1.66 \pm 0.33 \times 10^{7} \mathrm{M}^{-1}\right.$; $\alpha_{\text {IIb }} \beta_{3}\left(\beta_{1-2}\right), K_{\mathrm{a}}=4.55 \pm 0.77 \times 10^{7} \mathrm{M}^{-1}$ ) (ref. 18). Mean CHO a
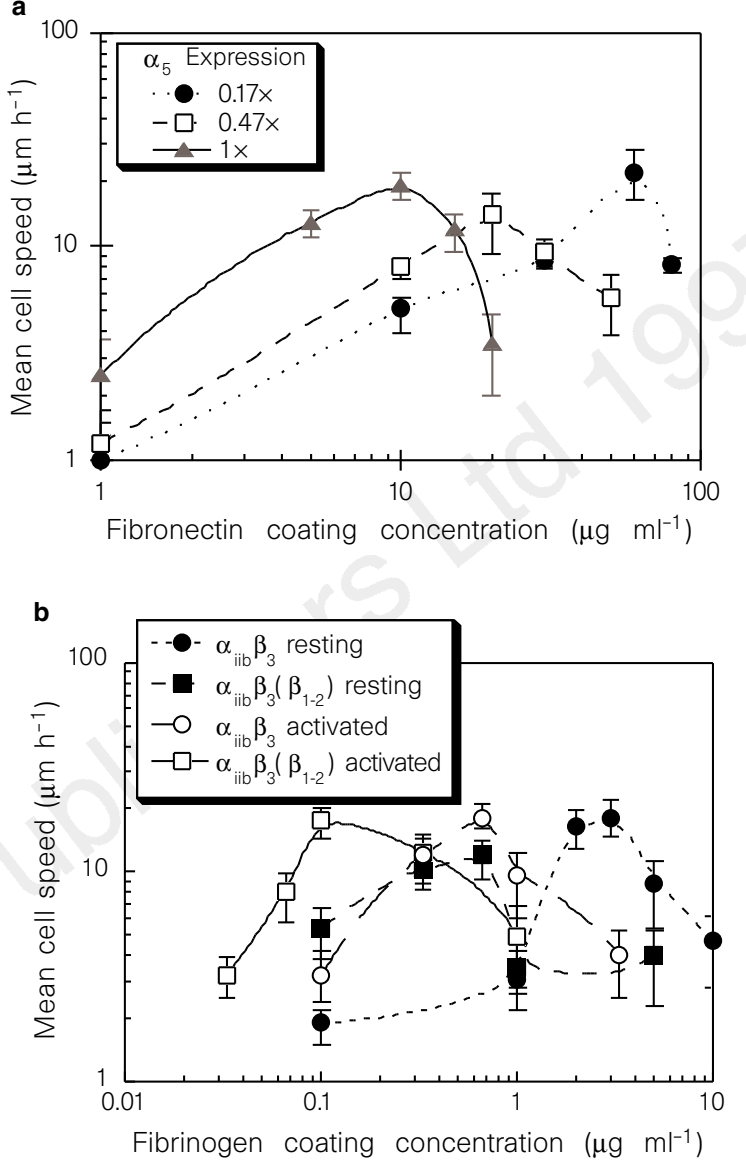

Figure 1 The speed of cell migration depends on substrate extracellular-matrix concentration, integrin expression level, and integrin-ligand affinity. Mean cell migration speed is determined using image analysis to track centroids of $\mathrm{CHO}$ cells with different integrin expression (a) and integrin-ligand affinity (b). Receptor expression was varied by transfecting $\alpha_{5}$-deficient $\mathrm{CHO}$ B2 cells with human $\alpha_{5}$ and sorting populations with different expression. Integrin-ligand affinity was varied by transfecting $\mathrm{CHO}$ cells with $\alpha_{\| \mathrm{lb}} \beta_{3}$ and $\alpha_{\| \mathrm{lb}} \beta_{3}\left(\beta_{1-2}\right)$, a higher-affinity mutant. These integrins were also activated by incubation with monoclonal antibody 62 (anti-LIBS2 antibody). Error bars represent 95\% confidence intervals on the mean cell speed. CHO-cell populations with different integrin expression (a) or integrin-ligand affinity (b) all have a biphasic migration-speed dependence on fibronectin concentration. As $\alpha_{5}$ expression (a) or $\alpha_{\| b} \beta_{3}$-fibrinogen affinity increases (b), the extracellular-matrix concentration promoting maximal migration decreases; at low concentrations, migration speed increases as expression or affinity increases, whereas at high concentrations, migration speed decreases as expression or affinity increases. Maximum attainable migration speed is not a function of integrin expression or affinity.

cell migration speed, measured by time-lapse video-microscopy, exhibits a biphasic dependence on extracellular-matrix ligand concentration regardless of integrin expression level (the $\alpha_{5} \beta_{1}$ receptor on fibronectin; Fig. 1a) or integrin-ligand binding affinity (the $\alpha_{\mathrm{IIb}} \beta_{3}$ receptor on fibrinogen; Fig. $1 \mathrm{~b}$ ). The maximum attainable cell speed remains the same in all cases; only the position of the biphasic curve is shifted. At low ligand concentrations, cell speed increases as integrin expression or binding affinity increases, whereas at high ligand concentrations, cell speed increases as integrin expression or binding affinity decreases. At intermediate ligand concentrations, intermediate integrin expression levels and intermediate bindingaffinity states result in greatest cell speed. At maximum migration speeds $\left(10-20 \mu \mathrm{mh}^{-1}\right), \mathrm{CHO}$ cells are moderately spread and move by extending multiple lamellae in different directions. Some 

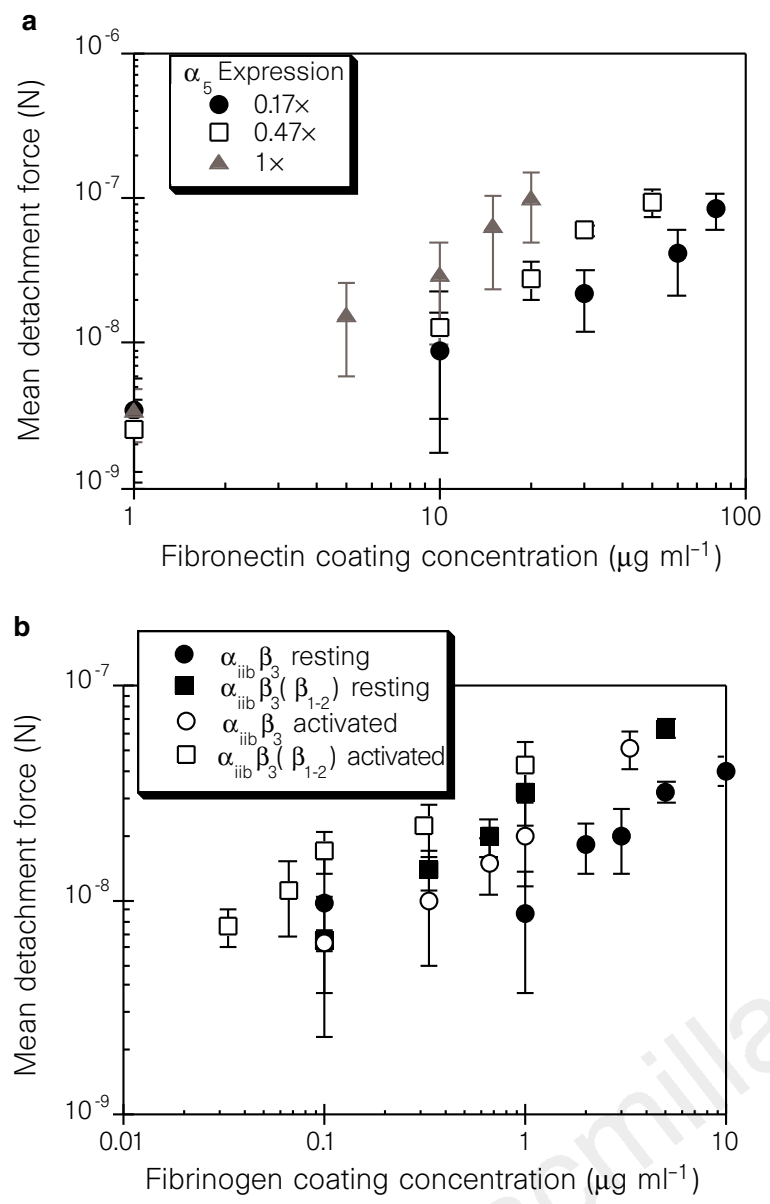

Figure 2 Cell-substratum adhesiveness increases as extracellular-matrix concentration, integrin expression, and integrin-ligand affinity increase. Shortterm mean cell detachment force, measured by shear-flow detachment, was measured for $\mathrm{CHO}$ cells with different levels of integrin expression and integrinligand affinity. Receptor expression was varied by transfecting $\alpha_{5}$-deficient $\mathrm{CHO}$ B2 cells with human $\alpha_{5}$ and sorting populations with different expression levels. Integrin-ligand affinity was varied by transfecting $\mathrm{CHO}$ cells with $\alpha_{\| b} \beta_{3}$ and $\alpha_{\| b} \beta_{3}\left(\beta_{1-2}\right)$, a higher-affinity mutant. These integrins were also activated by incubation with monoclonal antibody 62 (anti-Libs2 antibody). Error bars represent $95 \%$ confidence intervals on the mean detachment force. In each cell population the mean detachment force increases with the extracellular-matrix concentration. At every concentration, the mean detachment force increases as integrin expression (a) or integrin-ligand affinity (b) increases.

lamellae are stable and move the cell in the direction of their extensions, but other lamellae retract. At ligand concentrations lower than that giving rise to the maximum speed, the cells are more rounded but still extend lamellae, which are smaller and shorter lived than lamellae in migrating cells; these unstable lamellae cannot move the cell body. At ligand concentrations higher than that giving rise to the maximum speed, the cells are very spread and extend lamellae in a manner similar to migrating cells; the cell body does not move well, presumably because it cannot release adhesions to the substrate.

Short-term mean cell detachment force, measured by a shearflow detachment assay ${ }^{19}$ after a 20 -min incubation, increases with ligand concentration at each integrin expression level or affinity state (Fig. 2). At any ligand concentration, mean detachment force a

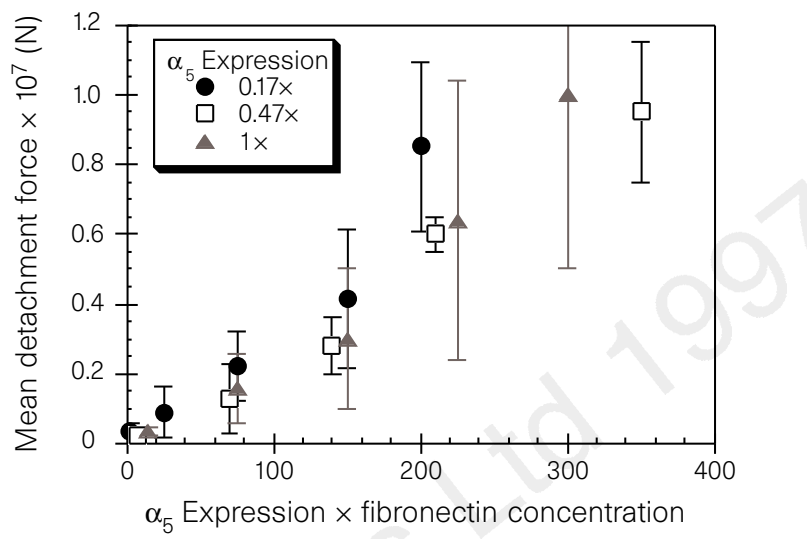

b

Relative $\alpha_{5}$ expression

Fibronectin concentration at maximum speed $\left.(\mu \mathrm{g} \mathrm{ml})^{-1}\right)$

Peak fibronectin concentration $\times \alpha_{5}$ expression

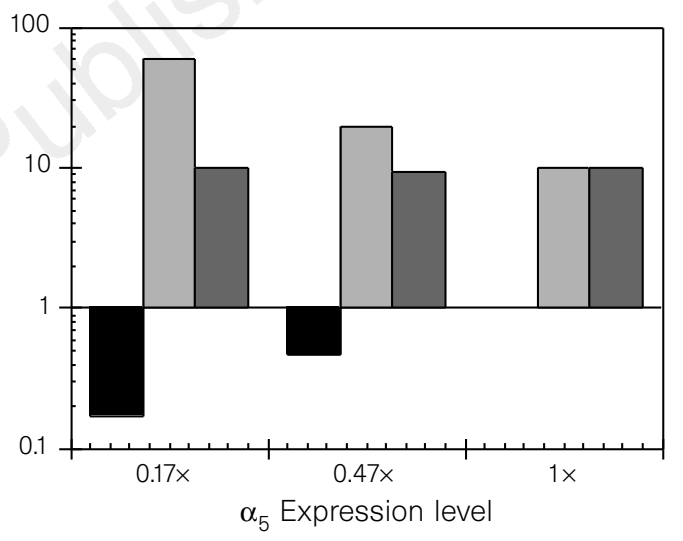

Figure 3 The number of cell-substratum bonds seems to determine cellsubstratum adhesiveness and migration speed. At constant receptor-ligand affinity, the number of cell-substratum bonds is approximately linearly proportional to the product of extracellular-matrix concentration and receptor expression. Mean cell detachment force increases linearly with this product at each expression level (a). Thus short-term cell-substratum adhesiveness appears to be a linear function of the number of cell-substratum bonds. The product of $\alpha_{5}$ expression and fibronectin concentration remains constant at the maximum migration speed (b), suggesting the existence of an optimal receptor occupancy at the maximum migration speed. 


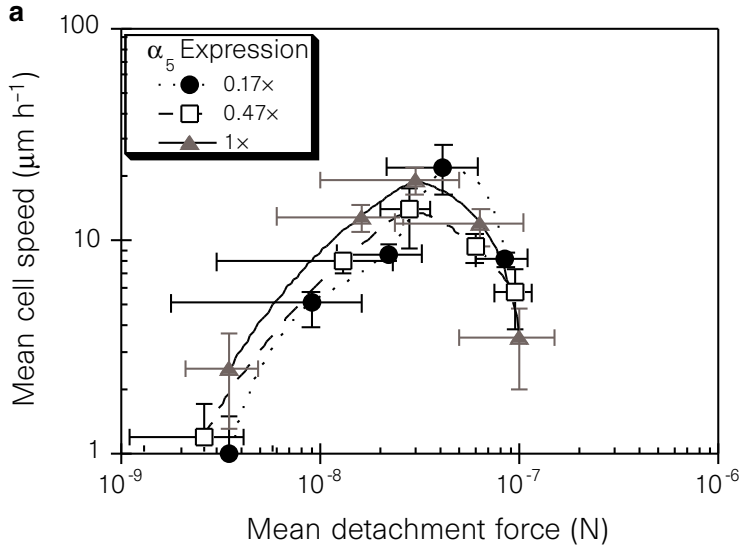

b

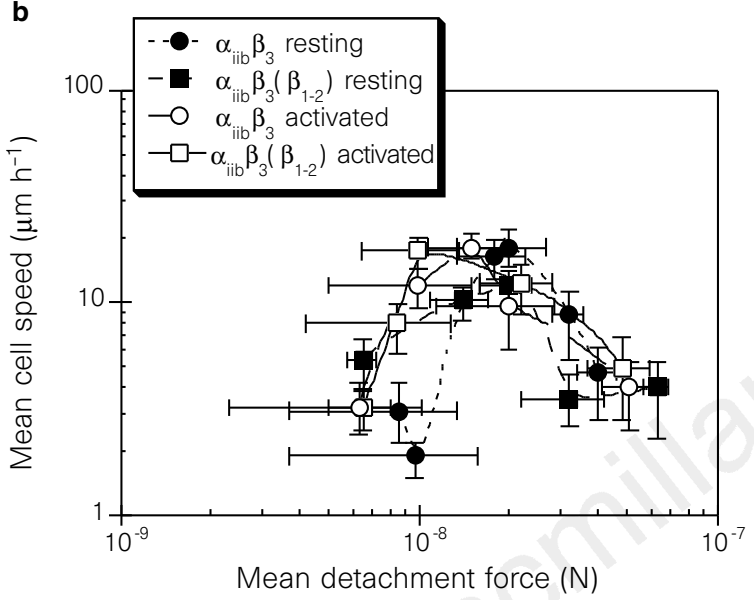

Figure 4 Cell migration speed (Fig. 1) correlates with cell-substratum adhesiveness (Fig. 2) as extracellular-matrix concentration, integrin expression, and integrin-ligand affinity change. Cell speed was measured by image analysis of cell centroids as a function of time, and detachment force was measured by shear-flow detachment. Error bars represent 95\% confidence intervals on the mean cell speed and detachment force. CHO B2 cells transfected with human $\alpha_{5}$ and sorted into populations with different relative $\alpha_{5}$ expression demonstrate that, as fibronectin substratum concentration or $\alpha_{5}$ expression change, the relationship between migration speed and mean detachment force is a constant, biphasic function (a). As $\alpha_{\| b} \beta_{3}$-fibrinogen affinity increases owing to the mutation from $\beta_{3}$ to $\beta_{3}\left(\beta_{1-2}\right)$ and to activation induced by monoclonal antibody 62 , the cell migration-speed dependence on short-term adhesiveness remains a constant, biphasic relationship (b). Maximum speed occurs at 2-4 $\times 10^{-8} \mathrm{~N}$ for both $\alpha_{5} \beta_{1-}$ and $\alpha_{\| b} \beta_{3}$-mediated migration, suggesting that these receptors can interact with the cytoskeleton and transmit intracellular motile forces similarly as extracellularmatrix concentration, integrin expression, and integrin-ligand affinity vary.

has the same linear relationship to the product of $\alpha_{5}$ expression and fibronectin concentration (Fig. 3a), suggesting that the short-term mean detachment force is proportional to the number of cellsubstratum bonds. (At high ligand concentrations there may be significant receptor depletion, yielding an asymptotic plateau in this plot.) The fibronectin concentration allowing maximum migration speed is inversely proportional to the $\alpha_{5}$ expression level, so that the product of the fibronectin concentration at maximum cell speed and the $\alpha_{5}$ expression level is constant over the range of $\alpha_{5}$ expression levels in this study (Fig. 3b). Because this product represents integrin-ligand bond number, it can be inferred that maximum migration occurs at an optimal, intermediate level of receptor occupancy.

To examine the relationship between migration speed and cell- substratum adhesiveness, we replotted cell migration speed as a function of detachment force (Fig. 4). Cell migration speed is a constant, biphasic function of cell-substratum adhesiveness as integrin expression or integrin-ligand binding affinity changes. The presence of an optimum adhesiveness for cell migration indicates that modulation of ligand concentration, integrin expression, and integrin affinity can be used to alter cell migration speed through changes in the short-term adhesive interaction between the cell and substratum. Relatively small changes in integrin expression or affinity can lead to substantial changes in migration speed. These variables seem to contribute quantitatively to short-term cell adhesion by altering the number of cell-substratum bonds. Both the $\alpha_{5} \beta_{1}$-fibronectin and the $\alpha_{\mathrm{IIb}} \beta_{3}$-fibrinogen bonds promote maximum cell speed at a cell-substratum detachment force of $2-4 \times 10^{-8} \mathrm{~N}$, suggesting that integrins with different ligandrecognition specificities can transmit intracellular motile forces similarly. Locomoting fibroblasts exert traction forces of about $20 \times 10^{-8} \mathrm{~N}$ (ref. 20). These detachment forces and traction forces are consistent with the mathematical model prediction that maximum cell speed occurs at an adhesiveness to contractile force ratio of $<1$ (ref. 14). High cell-substratum adhesiveness probably hinders cell migration by obstructing the release of adhesions at the rear of the cell ${ }^{12-23}$. Videotaped observations of cells at high adhesiveness reveal lamellipod extension and retraction, but little movement of the cell body. At low cell-substratum adhesiveness, however, inhibition of rear release is an unlikely explanation for reduced migration rates. Except at the lowest levels of adhesiveness, the cells are still able to extend lamellae, but these lamellae are smaller and less frequently extended that those in more adherent cells. Decreased rate of lamellipodal extension or more likely, decreased probability of formation of a stable attachment to the surface by the lamellae, probably account for the reduced migration at low adhesiveness ${ }^{24}$.

Additional variables such as lamellipodal extension, intracellular force generation, integrin clustering and avidity effects, and integrin signalling are important to the processes of cell adhesion and cell migration $^{4,12,13}$. For example, overexpression of FAK in CHO cells results in increased cell migration but does not alter cell spreading or adhesion, at least as measured in a particular assay ${ }^{25}$. Nonetheless, our results suggest that short-term cell-substratum adhesiveness is rate limiting in determining migration speed as the linkage between integrin and the extracellular matrix is altered, and can serve as a unifying parameter in understanding the influence of various molecular properties on migration speed.

This interrelation between migration and adhesiveness has important implications in clinical applications, such as various molecular therapeutic approaches to cancer ${ }^{26}$. Where decreased cell migration is generally desirable, targeting receptor expression or receptor-ligand binding affinity are potentially effective strategies. In biomaterials and tissue-engineering applications, increased migration is often desired ${ }^{27}$. Altering the extracellular-matrix ligand concentration seems to be the easiest means of affecting cell-substratum adhesiveness, but other approaches to change receptor number or receptor-ligand binding affinity, such as soluble binding competitors or drugs affecting receptor-ligand or receptor-cytoskeleton coupling, could allow additional control of cell adhesiveness and migration in a quantitatively predictable manner.

\section{Methods}

Cell preparation. CHO B2 cells ${ }^{7}$ were transfected with a human $\alpha_{5} \mathrm{cDNA}^{28}$ using lipofectamine (GIBCO-BRL), as described in the manufacturer's protocols. Generation of CHO cells expressing $\alpha_{\text {IIb }} \beta_{3}$ and $\alpha_{\text {IIb }} \beta_{3}\left(\beta_{1-2}\right)$ has been described $^{17}$. The cells were grown in DMEM containing 10\% FBS, $2 \mathrm{mM}$ glutamine, and $1 \%$ non-essential amino acids. The transfected cells were selected in DME containing $100 \mu \mathrm{g} \mathrm{ml}^{-1} \mathrm{G} 418$ and maintained in DME containing $50 \mu \mathrm{g} \mathrm{ml}^{-1} \mathrm{G} 418$. Cells expressing human $\alpha_{5}$ were selected 
from non-expressors by flow cytometry. Quantitative cell-surface expression of integrins was determined by flow cytometry ${ }^{29}$ using human $\alpha_{5}$ antibody 6F4 at 1:4 dilution of hybridoma supernatant to assay $\alpha_{5}$ expression and non-inhibitory $\alpha_{\mathrm{II}} \beta_{3}$ antibody D57 at 1:200 dilution of mouse ascites to assay $\alpha_{\mathrm{II}} \beta_{3}$ expression. Cells expressing $\alpha_{5}$ were sorted into three populations with different relative expression levels, and cells expressing $\alpha_{\mathrm{IIb}} \beta_{3}\left(\beta_{1-2}\right)$ were sorted into similar surface-expression profiles to $\alpha_{\mathrm{II}} \beta_{3}$ transfected cells. Both $\alpha_{\mathrm{II}} \beta_{3}$ and $\alpha_{\mathrm{II}} \beta_{3}\left(\beta_{1-2}\right)$ were activated to the highaffinity state by incubation with $100 \mu \mathrm{g} \mathrm{ml}^{-1}$ monoclonal antibody 62 (anti-LIBS2 antibody).

Adhesion assay. $\mathrm{CHO}$ cells were incubated on silaned fibrinogen- or fibronectin (Sigma)-coated glass slides for $20 \mathrm{~min}$ in serum-free OptiMEM 1 (GIBCO-BRL). The slide was placed in a shear-stress flow chamber ${ }^{19}$, which produces a linear gradient in shear with position along the centre line: $\tau_{w}=\left(6 \mu Q / h^{2} w_{1}\right) /(1-(z / L))$ where $\tau_{w}$ is the surface shear stress, $\nu$ the fluid viscosity, $Q$ the flow rate, $h$ the channel height, $w_{1}$ the channel width at the origin of the flow field, $z$ the distance from the origin along the centre line, and $L$ the length of the flow field. PBS with $\mathrm{Ca}^{2+}$ and $\mathrm{Mg}^{2+}$, heated to $37^{\circ} \mathrm{C}$, flowed through the chamber for $5 \mathrm{~min}$ to detach the cells. Cells in 20 fields along the slide were counted before and after flow detachment. Shear stress was calculated for each field and converted to shear force $\left(F_{\mathrm{s}}\right)$ by approximating cell morphology as a hemispherical cap, such that $F_{\mathrm{s}}=2.15 \pi\left(r_{\mathrm{p}}^{2}+h^{2}\right) \tau_{w}$ where $r_{\mathrm{p}}$ is the hemispherical cap radius and $h$ the height. The fraction of cells detached as a function of shear force was fit to the integrals of logarithmic normal probability density-function distributions to determine the mean shear force for detachment of $50 \%$ of the cells. Five detachment assays were performed for each cell type at each extracellular-matrix concentration, and mean detachment forces were averaged.

Migration assay. $\mathrm{CHO}$ cells were incubated on silaned, fibrinogen- or fibronectin-coated coverslips for $3 \mathrm{~h}$ in serum-free OptiMEM 1. Real-time digital image processing was used to acquire images and calculate cell centroid position as a function of time. The image-processing software (Engineering Technology Center, Mystic, CT) identifies cell boundaries from phase-contrast images and measures cell centroid position. We scanned 5-10 cells per field in 10 different fields every $15 \mathrm{~min}$ for $12 \mathrm{~h}$. The mean-squared displacement of the cell centroid as a function of time was calculated for each cell using nonoverlapping time intervals. The mean-squared displacements were averaged and fit to a persistent random walk mode ${ }^{30}$ to calculate cell speed, $S$, and persistence time, $P:\left\langle\mathrm{d}^{2}(t)\right\rangle=2 S^{2} P\left[t-P\left(1-\mathrm{e}^{-t / P}\right)\right]$.

Received 13 November; accepted 19 December 1996

1. Hynes, R. O. Cell 69, 11-25 (1992).

2. Cheresh, D. A. Adv. Mol. Cell Biol. 6, 225-252 (1993).

3. Schwartz, M. A. Schaller, M. D. \& Ginsberg, M. H. Annu. Rev. Cell Dev. Biol. 11, 549-599 (1995).

4. Lauffenburger, D. A. \& Horwitz, A. F. Cell 84, 359-369 (1996).

5. Goodman, S. L., Risse, G. \& van der Mark, K. J. Cell Biol. 109, 799-809 (1989)

6. DiMilla, P. A., Stone, J. A., Quinn, J. A., Albelda, S. A. \& Lauffenburger, D. A. J. Cell Biol. 122, 729-737 (1993).

7. Bauer, J. S, Schreiner, C. L., Giancotti, F. G., Ruoslahti, E \& Juliano, R. L. J. Cell Biol. 116, 477-487 (1992).

8. Giancotti, F. G. \& Ruoslahti, E. Cell 60, 849-859 (1990).

9. Keely, P. J., Fong, A. M., Zutter, M. M. \& Santoro, S. A. J. Cell Sci. 108, 595-607 (1995).

10. Duband, J.-L., Dufour, S., Yamada, S. S., Yamada, K. M. \& Thiery, J. P. J. Cell Sci. 98, 517-532 (1991).

11. Kuijpers, T. W. et al. J. Exp. Med. 178, 279-284 (1993).

12. Huttenlocher, A., Ginsberg, M. H. \& Horwitz, A. F. J. Cell Biol. 134, 1551-1562 (1996).

13. Huttenlocher, A., Sandborg, R. R. \& Horwitz, A. F. Curr. Opin. Cell Biol. 7, 697-706.

14. DiMilla, P. A., Barbee, K. \& Lauffenburger, D. A. Biophys. J. 60, 15-37 (1991).

15. Regen, C. M. \& Horwitz, A. F. J. Cell Biol. 119, 1347-1359 (1992).

16. Palecek, S. P. Schmidt, C. E. Lauffenburger, D. A. \& Horwitz, A. F. J. Cell Sci. 109, 941-952 (1996).

17. Bajt, M. L., Loftus, J. C., Gawaz, M. P. \& Ginsberg, M. H. J. Biol. Chem. 267, 22211-22216 (1992).

18. Frelinger, A. L., Du, X., Plow, E. F. \& Ginsberg, M. H. J. Biol. Chem. 266, 17106-17111 (1991).

19. Powers, M. J., Rodriguez, R. E. \& Griffith, L. G. Biotechnol. Bioeng. (in the press).

20. Oliver, T. N., Lee, J. \& Jacobson, K. Semin. Cell Biol. 5, 139-147 (1994).

21. Abercrombie, M., Heaysman, J. E. M. \& Pegrun, S. M. Exp. Cell Res. 59, 393-398 (1970).

22. Marks, P. W., Hendey, B. \& Maxfield, F. R. J. Cell Biol. 112, 149-158 (1991).

23. Jay, P. Y., Pham, P. A., Wong, S. A. \& Elson, E. L. J. Cell Sci. 108, 387-393 (1995).

24. Wessels, D., Vawter-Hugart, H., Murray, J. \& Soll, D. R. Cell Motil. Cytoskeleton 27, 1-12 (1994).

25. Cary, L. A., Chang, J. F \& Guan, J. J. Cell Sci. 109, 1787-1794 (1996).

26. Varner, J. A. \& Cheresh, D. A. Curr. Opin. Cell Biol. 8, 724-730 (1996).

27. Langer, R. \& Vacanti, J. Science 260, 920-926 (1993).

28. Argraves, W. S. et al. J. Cell Biol. 105, 1183-1190 (1987).

29. Loftus, J. C. et al. Science 249, 915-918 (1990).

30. Dunn, G. A. Agents Actions (suppl.) 22, 14-33 (1983)

Acknowledgements. We thank R. Isberg for 6F4 antibody, L. Reichardt for $\alpha_{\mathrm{s}} \mathrm{cDNA}$, and R. Juliano for CHO B2 cells. This work was supported by grants from the NIH to D.A.L., A.F.H., J.C.L. and M.H.G., and a Whitaker Foundation graduate fellowship in Biomedical Engineering to S.P.P.

Correspondence and requests for materials should be addressed to D.A.L. (e-mail: lauffen@mit.edu).

\section{MAP3K-related kinase involved in NF- $\kappa$ B induction by TNF, CD95 and IL-1}

\author{
Nikolai L. Malinin, Mark P. Boldin, Andrei V. Kovalenko \& \\ David Wallach
}

Department of Membrane Research and Biophysics, The Weizmann Institue of Science, 76100 Rehovot, Israel

Several members of the tumour-necrosis/nerve-growth factor (TNF/NGF) receptor family activate the transcription factor NF$\kappa B$ through a common adaptor protein, Traf2 (refs 1-5), whereas the interleukin 1 type-I receptor activates NF- $\mathrm{B}$ independently of Traf2 (ref. 4). We have now cloned a new protein kinase, NIK, which binds to Traf 2 and stimulates NF- $\kappa B$ activity. This kinase shares sequence similarity with several MAPKK kinases. Expression in cells of kinase-deficient NIK mutants fails to stimulate NF$\kappa B$ and blocks its induction by TNF, by either of the two TNF receptors or by the receptor CD95 (Fas/Apo-1), and by TRADD, RIP and MORT1/FADD, which are adaptor proteins that bind to these receptors. It also blocked NF- $\kappa \mathrm{B}$ induction by interleukin-1. Our findings indicate that NIK participates in an NFsignalling cascade common to receptors of the TNF/NGF family and to the interleukin-1 type-I receptor.

NF- $\kappa \mathrm{B}$, a ubiquitously expressed transcription factor comprising a homo- or heterodimer of DNA-binding proteins related to the proto-oncogene c-Rel, controls the expression of many immuneand inflammatory-response genes. In most cells NF- $\kappa \mathrm{B}$ exists in a

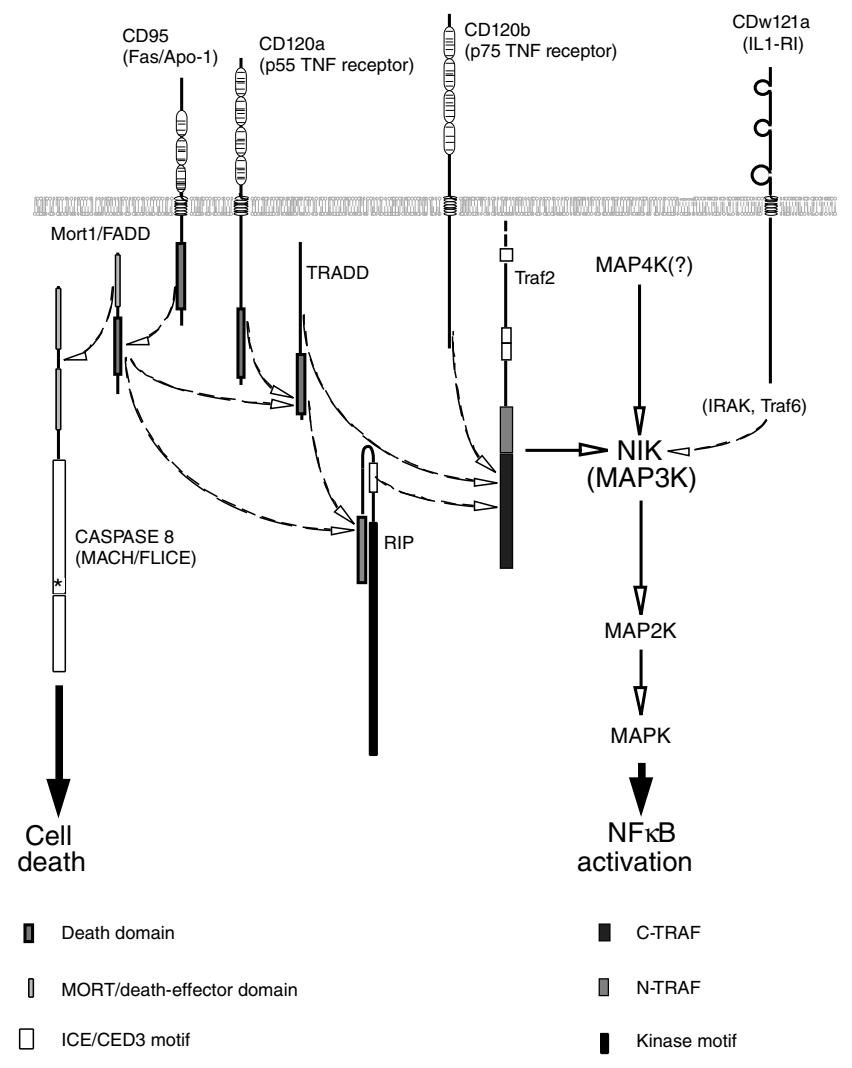

Figure 1 The known protein-protein interactions through which the TNF receptors (p55, or CD120a, and p75, or CD120b), CD95 (Fas/Apo-1) and CDw121a (the IL-1 type-I receptor) might affect the activity of NIK. 
system $^{10,11}$ (expected to be comparable to that of the present reference system) is not known with certainty ${ }^{11}$. If it is assumed that a $20-30 \%$ yield of 'permanent' $\mathrm{DQ}^{+}$results (that is, BET eliminates $70-80 \%$ of initially formed $\mathrm{DQ}^{+\cdot}$ ), then the $\sim$ four-fold increase in charge-separation efficiency observed here for the spatially organized system is all that could possibly be realized. That is, to the extent that the efficiency of the BET in the reference system is as low as $70-80 \%$, the four-fold increase for the dyad system indicates that the strategy used here is indeed highly effective in reducing the effect of BET. We plan further work to document the BET reaction efficiency by time-resolved diffuse reflectance measurements and to attempt to improve the particle/solutionphase electron transfer process.

Here we have reported a specific application of the adjacent-cage assemblies to photoinduced charge-separation; we note that the synthetic methods which have been ${ }^{7}$ (and continue to be) developed should prove useful for a wide range of applications. Future efforts will be devoted to the construction of zeolite-entrapped assemblies consisting of redox-active complexes or photosensitizers coupled to coordinatively unsaturated, redox-active complexes which are capable of binding and activating small molecular substrates, such as the oxygen molecule and the oxides of carbon and nitrogen.

Received 14 October 1996; accepted 25 March 1997.

1. Breck, D. W. Zeolite Molecular Sieves (Wiley, New York, 1974).

2. Weitkamp, J., Karge, H. G., Pfiefer, H. \& Holderich, W. (eds) Zeolites and Related Materials: State of the Art (Elsevier, Amsterdam, 1994).

3. Kalyanasundaram, K. Photochemistry in Microheterogeneous Systems (Academic, New York, 1987)

4. O’Regan, B. \& Grätzel, M. Nature 353, 737-740 (1991).

. Krueger, J. A., Meyer, J. E. \& Mallouk, T. E. J. Am. Chem. Soc. 110, 8232-8234 (1988).

De Vos, D. E. et al. J. Inclus. Phenom. Mol. Recogn. Chem. 21, 185-213 (1995).

Sykora, M., Maruszewski, K., Treffert-Ziemelis, S. M. \& Kincaid, J. R. J. Am. Chem. Soc. (submitted)

. DeWilde, W., Peters, G. \& Lunsford, L. H. J. Phys. Chem. 84, 2306-2310 (1980)

Quayle, W. H. \& Lunsford, J. H. Inorg. Chem. 21, 97-103 (1982).

10. Dutta, P. K. \& Turbeville, W. J. Phys. Chem. 96, 9410-9416 (1992).

11. Borja, M. \& Dutta, P. K. Nature 362, 43-45 (1993).

12. Willner, J., Yang, J., Loane, C., Otvos, J. W. \& Calvin, M. J. Phys. Chem. 85, 3277-3282 (1981).

13. Slama-Schwork, A., Ottolenghi, M. \& Avnir, D. Nature 355, 240-242 (1992).

14. Maruszewski, K., Strommen, D. P., Handrich, K. \& Kincaid, J. R. Inorg. Chem. 30, 4579-4582 (1991).

15. Maruszewski, K., Strommen, D. P., Handrich, K. \& Kincaid, J. R. J. Am. Chem. Soc. 115, 8345-8350 (1993)

16. Maruszewski, K. \& Kincaid, J. R. Inorg. Chem. 34, 2002-2006 (1995).

17. Toma, H. E., Auburn, P. R., Dodsworth, E. S., Golovin, M. N. \& Lever, A. B. P. Inorg. Chem. 26, $4257-$ 4263 (1987).

Acknowledgements. This work was supported by the Division of Chemical Sciences, US Department of Energy.

Correspondence and requests for materials should be addressed to J.R.K. (e-mail: Kincaid) @vms.csd.mu.edu).

\section{Total synthesis of the potential anticancer vaccine $\mathrm{KH}-1$ adenocarcinoma antigen}

\section{Prashant P. Deshpande ${ }^{\star}$ \& Samuel J. Danishefsky ${ }^{\star \dagger}$}

${ }^{\star}$ Laboratory for Bioorganic Chemistry, Sloan-Kettering Institute For Cancer Research, 1275 York Avenue, New York, New York 10021, USA

$\dagger$ Department of Chemistry, Columbia University, Havemeyer Hall, New York, New York 10027, USA

Human tumours are often marked by the expression of unusual carbohydrate structural motifs ${ }^{1-3}$. These carbohydrate domains are manifested as cell-surface bound glycolipids or glycoproteins ${ }^{4}$. This raises the possibility of using cell-free equivalents of these domain compounds, obtained by total synthesis with a view towards triggering some level of immune response. In fact, the serum of mice immunized with fully synthetic compounds ${ }^{5-7}$ that mimic cell-surface tumour antigens has already been shown to recognize pertinent human cancer cell lines ${ }^{8}$. Further advances in this field depend critically on the availability of these tumourassociated carbohydrate antigens which cannot be readily isolated from natural sources in sufficient quantities. Here we present the successful total synthesis of an adenocarcinoma antigen, $\mathrm{KH}-1$, and of a bioconjugatable analogue which can bind to a carrier protein. These results illustrate the capabilities of oligosaccharide synthesis for reconstructing the challenging structural motifs characteristic of carbohydrate antigens, and thereby open up new possibilities for the development of anticancer vaccines.

The chances of success from the point of view of vaccinology will be higher with the greater specificity of the carbohydrate domain of the antigen. From this perspective, one such tumour antigen which attracted our notice is the glycolipid $\mathrm{KH}-1$, immunocharacterized by Hakomori and associates 9 . (We note that a total synthesis of $\mathrm{KH}-$ 1 antigen, by a classical route, was reported ${ }^{10}$ after submission of this Letter.) This antigen is apparently a highly telling marker for malignancy and pre-malignancies involving colonic adenocarcinoma. Arguments have been advanced ${ }^{10-12}$ asserting the structure of $\mathrm{KH}-1$ to be $\mathbf{1}$ (shown in Fig. 1). The nonasaccharide character of $\mathbf{1}$ is, from a structural standpoint, unique. In considering $\mathrm{KH}-1$ as a candidate for total synthesis we also noted the crystallographically derived presentation of monoclonal antibody BR96, bound to a Le $\mathrm{Le}^{\mathrm{y}}$ tetrasaccharide glycoside ${ }^{13}$. The structure of the Br96: Le $^{y}$ complex suggested that this antibody might have the capacity to recognize higher-order fucosylated arrays. With a view to addressing this question, as well as investigating the possibility of incorporating $\mathrm{KH}-1$ in a vaccine, we have directed considerable attention towards the total synthesis. Our inquiry was not limited to $\mathrm{KH}-1$ (1), but included congeners $^{14,15}$ (structure 2; Fig. 1) which are suitable for conjugation to appropriate bioactive carrier systems. We report here the attainment of these goals.

In conducting this project, we also hoped to address the important issue of 'strategy' in oligosaccharide synthesis. Of course in this field, as opposed to 'conventional' natural product synthesis, the basic building blocks are rather restricted and tend to bear obvious homology with readily recognized components of the target system. Nonetheless, as we show, there are considerable opportunities in the design of convergent strategies, which might lead to synthetic economies.

From this perspective we came to favour a plan which would build a hexasaccharide (structure 13 in Fig. 3), so differentiated in terms of its protecting patterns (see arrows) as to allow for the unveiling of the three free hydroxyls to serve as $\alpha$ fucosylation acceptor sites. In this way, perhaps, the three immunologically defining $\alpha$-fucose units could be introduced in one concurrent synthetic operation. Considerable thought was also directed to assembling the hexasaccharide with sound management of an otherwise potentially forbidding network of hydroxyl group functionalities. We found advantages in drawing from principles which emerged from the logic of glycal assembly ${ }^{16}$.

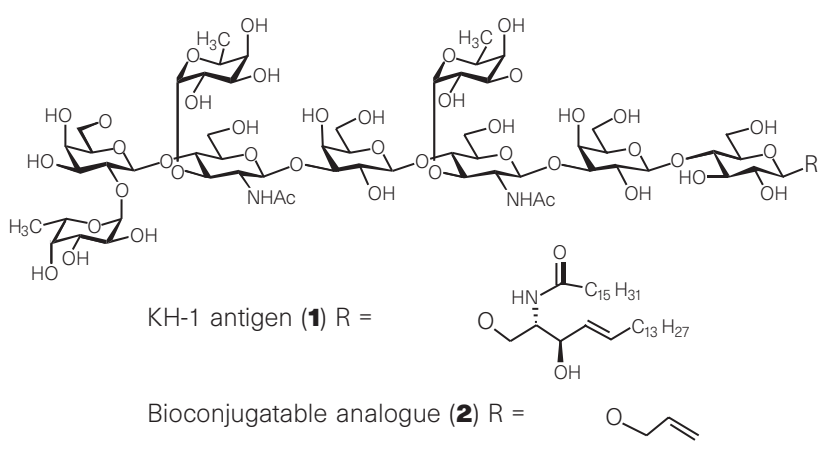

Figure 1 The structure of $\mathrm{KH}-1$ antigen and a congener that is suitable for conjugation to appropriate bioactive carrier systems. 


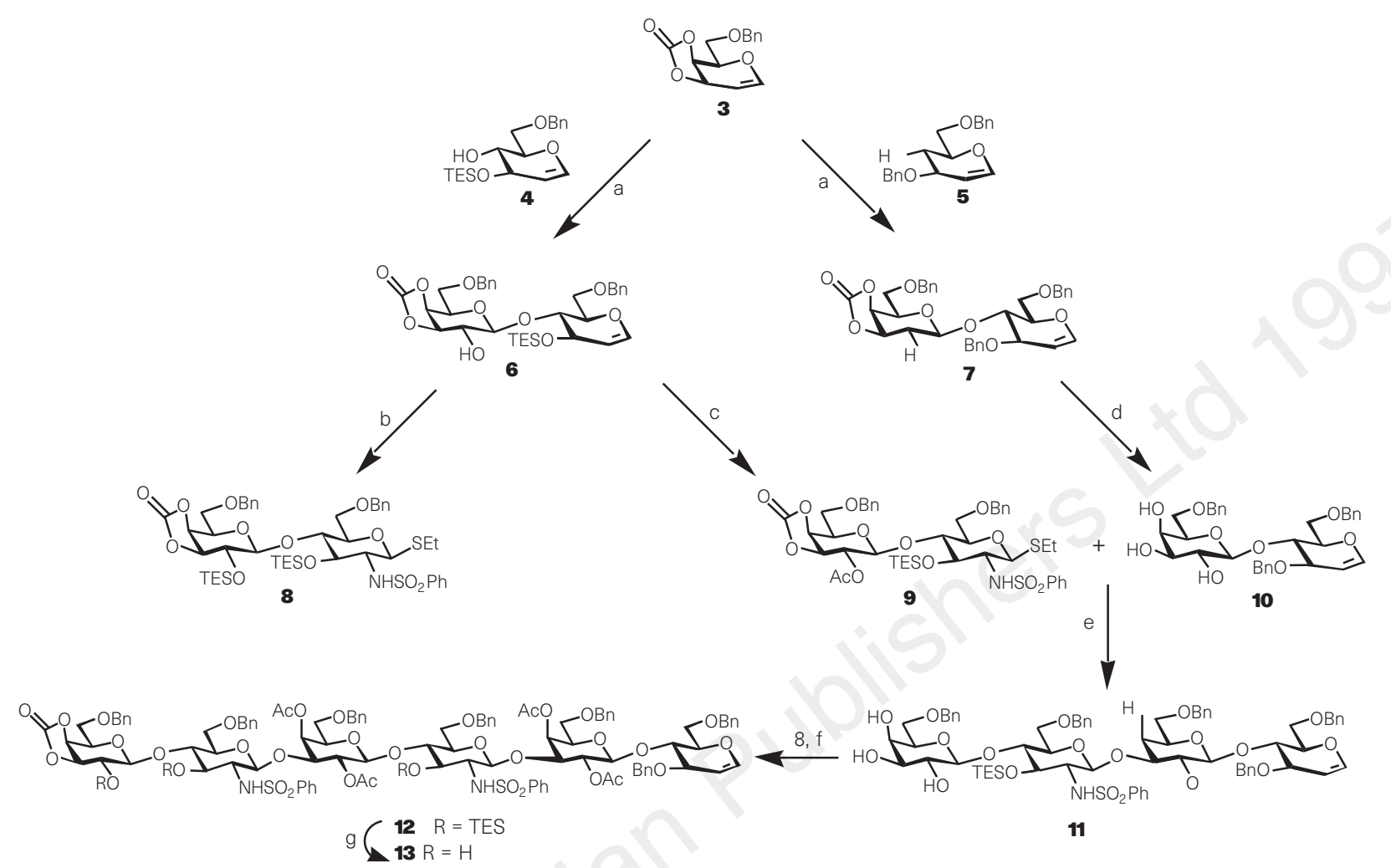

Figure 2 Reagents: a, (i) 3,3-diemthyldioxirane, $\mathrm{CH}_{2} \mathrm{Cl}_{2}$, (ii) $\mathbf{4}$ or $\mathbf{5}, \mathrm{ZnCl}_{2}$, THF $65 \%$ for $\mathbf{6}$ and $55 \%$ for 7; b, (i) TESOTf, $\mathrm{Et}_{3} \mathrm{~N}, \mathrm{CH}_{2} \mathrm{Cl}_{2} 92 \%$, (ii) I(coll) $)_{2} \mathrm{ClO}_{4}, \mathrm{PhSO}_{2} \mathrm{NH}_{2}, 4-\AA$ molecular sieves (MS), $\mathrm{CH}_{2} \mathrm{Cl}_{2},>90 \%$, (iii) LHMDS, EtSH, DMF >90\%; c, (i) $\mathrm{Ac}_{2} \mathrm{O}$, $\mathrm{Et}_{3} \mathrm{~N}, \mathrm{DMAP}, \mathrm{CH}_{2} \mathrm{Cl}_{2}, 95 \%$, (ii) I(coll) ${ }_{2} \mathrm{ClO}_{4}, \mathrm{PhSO}_{2} \mathrm{NH}_{2}, 4-\AA \mathrm{MS}, \mathrm{CH}_{2} \mathrm{Cl}_{2},>90 \%$, (iii) LHMDS, EtSH, DMF, (iv) $\mathrm{Ac}_{2} \mathrm{O}, \mathrm{Et}_{3} \mathrm{~N}, \mathrm{DMAP}, \mathrm{CH}_{2} \mathrm{Cl}_{2}, 85 \%$; $\mathrm{d}_{2} \mathrm{~K}_{2} \mathrm{CO}_{3}, \mathrm{MeOH} 80 \%$; e, (i) MeOTf, di-t-butylpyridine, $\mathrm{Et}_{2} \mathrm{O}: \mathrm{CH}_{2} \mathrm{Cl}_{2}$ (2:1), 4- $\AA$ MS (55\%), (ii) $\mathrm{K}_{2} \mathrm{CO}_{3}, \mathrm{MeOH}$
(85\%); f, (i) MeOTf, di-t-butylpyridine, $\mathrm{Et}_{2} \mathrm{O}: \mathrm{CH}_{2} \mathrm{Cl}_{2}$ (2: 1), 4- $\AA \mathrm{MS}$ (60\%), (ii) $\mathrm{Ac}_{2} \mathrm{O}$, Py, DMAP, $\mathrm{CH}_{2} \mathrm{Cl}_{2}$ (95\%); g, TBAF: $\mathrm{AcOH}$ (93\%). (THF, tetrahydrofuran; TESOTf, triethylsilyl trifluoromethanesulphonate; I(coll) $)_{2} \mathrm{ClO}_{4}$, Bis-sym-collidine iodonium perchlorate; LHMDS, lithium bis(trimethylsilyl)amide; DMF, N,N-dimethylformamide; DMAP, N,N-dimethylaminopyridine; MeOTf, methyl trifluoromethanesulphonate; TBAF, tetrabutylammonium fluoride; OBn, O-benzyl.)

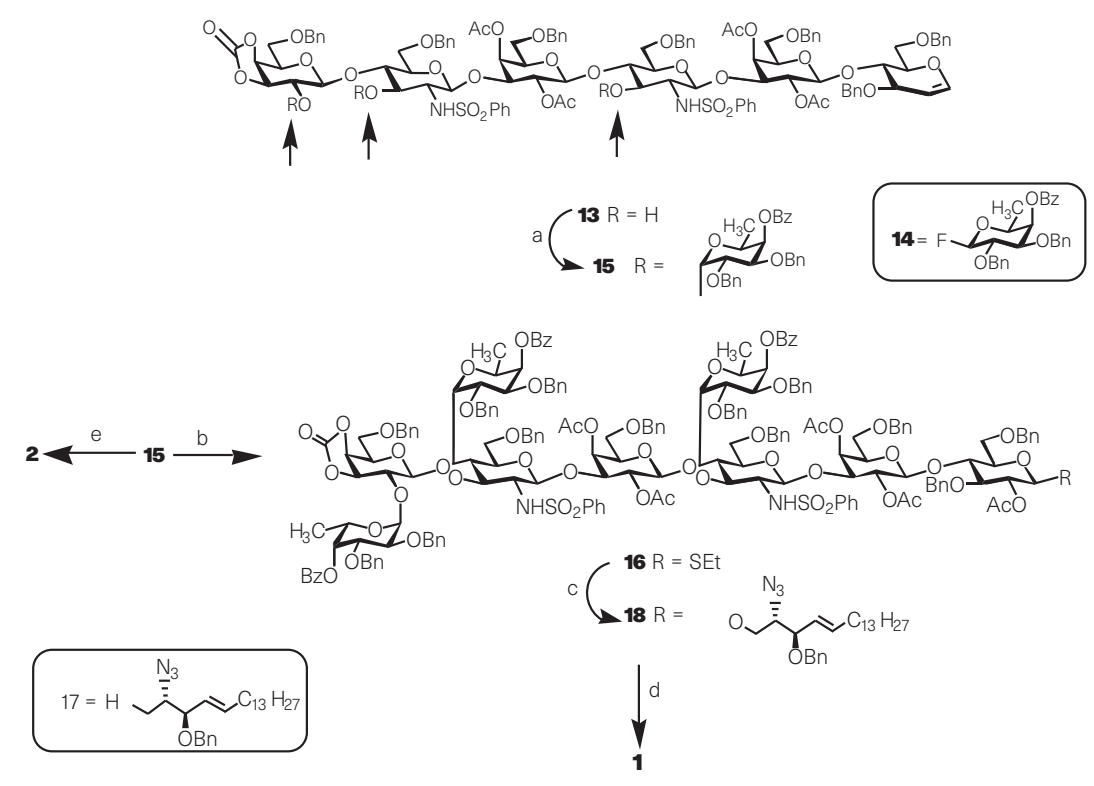

Figure $3 \mathrm{a}, \mathbf{1 4}, \mathrm{Sn}(\mathrm{OTf})_{2}$, toluene : $\operatorname{THF}(10: 1)$, 4-Å molecular sieve (MS) (60\%); b, (i) 3,3-dimethyldioxirane, $\mathrm{CH}_{2} \mathrm{Cl}_{2}$, (ii) $\mathrm{EtSH}, \mathrm{CH}_{2} \mathrm{Cl}_{2}, \mathrm{H}^{+}$(cat.), (iii) $\mathrm{Ac}_{2} \mathrm{O}, \mathrm{Py}_{1} \mathrm{CH}_{2} \mathrm{Cl}_{2} 60 \%$ (three steps); c, 17, MeOTf, $\mathrm{Et}_{2} \mathrm{O}: \mathrm{CH}_{2} \mathrm{Cl}_{2}$ (2:1), 4- $\AA$ MS (55\%); d, (i) Lindlar's catalyst, $\mathrm{H}_{2}$, palmitic anhydride, EtOAc, $85 \%$, (ii) $\mathrm{Na}^{0} \mathrm{NH}_{3}$, THF; (MeOH quench), (iii) $\mathrm{Ac}_{2} \mathrm{O}, \mathrm{Et}_{3} \mathrm{~N}, \mathrm{DMAP}, \mathrm{CH}_{2} \mathrm{Cl}_{2}$, (iv) $\mathrm{MeONa}, \mathrm{MeOH}, 70 \%$ (three steps); e, (i) $\mathrm{Na}^{0}$, $\mathrm{NH}_{3}$, THF; ( $\mathrm{MeOH}$ quench), (ii) $\mathrm{Ac}_{2} \mathrm{O}, \mathrm{Et}_{3} \mathrm{~N}, \mathrm{DMAP}, \mathrm{CH}_{2} \mathrm{Cl}_{2}$, (iii) 3,3-dimethyldioxirane, $\mathrm{CH}_{2} \mathrm{Cl}_{2}$, (iv) allyl alcohol, (v) $\mathrm{MeONa}, \mathrm{MeOH}, 60 \%$. ( $\mathrm{H}^{+}$(cat), catalytic acid; $\mathrm{Na}^{0}$, sodium; OBz, O-benzoyl.) 
Thus differentiated glycals 4 (ref. 17) and 5 were derived from D-glucal by exploiting the reliable reactivity preference of the $\mathrm{C}_{6}, \mathrm{C}_{3}$ and $\mathrm{C}_{4}$ hydroxyls $\left(\mathrm{C}_{6}>\mathrm{C}_{3}>\mathrm{C}_{4}\right)^{18,19}$; compounds 3-13 are shown in Fig. 2). Moreover, the fashioning of a clean $\alpha$-epoxide from galactal derivative 3 is well known ${ }^{16}$, as is the excellent $\beta$-galactosyl donating capacity of such an epoxide ${ }^{20}$. Coupling of this epoxide to acceptors $\mathbf{4}$ and $\mathbf{5}$ under mediation by anhydrous zinc chloride gave 6 and 7 respectively. The $\mathrm{C}_{2}{ }^{\prime}$ hydroxyl of the lactal derivative $\mathbf{6}$ was silylated and the resultant glycal linkage was subjected to overall suphonamido $(2 \alpha)$ ethanethiolation ${ }^{5,21}(1 \beta)$ to provide 8 . We note that in this product two of the three sites destined for eventual fucosylation have been distinguished. In a parallel experiment, the acetate derived from compound $\mathbf{6}$ was converted to intermediate 9 which carried the third eventual fucosylation centre at the site of its triethylsilyl (TES) protecting group. Cleavage of the carbonate linkage of $\mathbf{7}$ generated triol 10. Here, we could take advantage of another well appreciated preference ${ }^{22,23}$ which is that the glycosyl accepting site in such a triol tends to be at the $\mathrm{C}_{3}{ }^{\prime}$ hydroxyl group. Coupling of $\mathbf{1 0}$ and $\mathbf{9}$ afforded, after cleavage of the cyclic carbonate and acetate linkages, a pentaol (structure 11).

At this stage, we chanced the proposition that the 1, 2, 3 triol in the terminal ring, rather than the 1, 3 diol in the galactose ring adjacent to glycal would serve as the acceptor locus with donor $\mathbf{8}$. This in fact proved to be the case. The successful glycosylation was followed by acetylation of the four remaining hydroxyl groups. This sequence led to $\mathbf{1 2}$ and thence to $\mathbf{1 3}$ containing the three free hydroxyl sites targeted for fucosylation.

It proved possible to introduce the three $\alpha$-L-fucose residues in one step via donor 14 (ref. 24), thereby affording a 60\% yield of the nonasaccharide 15; compounds 14-18 are shown in Fig. 3. From this point, the protocols required to reach $\mathbf{1}$ and $\mathbf{2}$ were much influenced by our earlier work in the globo $\mathrm{H}$ series ${ }^{5-7}$. The application of this chemistry to reach the pre-conjugation allyl glycoside 2 is provided in Fig. 3. To reach the naturally occurring glycolipid antigen 1, we introduced a useful variation wherein the preceramide acceptor 17 was coupled to an anomeric thioethyl donor derived from the glycal epoxide $(\text { see } 15 \rightarrow 16)^{25,26}$ to generate compound $\mathbf{1 8 .}$

The structures of the final products $\mathbf{1}$ and $\mathbf{2}$ were fully substantiated by mass spectroscopy, by self-consistent NMR analysis and, in the case of 1 , by correspondence with the available fragmentary published data ${ }^{5}$. A direct material comparison was not possible because of the nonfeasibility of obtaining a sufficient quantity of $\mathrm{KH}-1$ antigen from natural sources. Owing to the synthesis reported here, access to this system is no longer an impassable problem.

Received 3 February; accepted 2 April 1997.

1. Hakomori, S. Aberrant glycosylation in cancer cell membranes as focused on glycolipids: overview and perspectives. Cancer Res. 45, 2405-2414 (1985).

2. Feizi, T. Carbohydrate antigens in human cancer. Cancer Surv. 4, 245-269 (1985).

3. Lloyd, K. O. Humoral immune responses to tumor-associated carbohydrate antigens. Cancer Biol. 2 421-431 (1991)

4. Hakomori, S. New directions in cancer therapy based on abberrant expression of glycosphingolipids: anti-adhesion and ortho-signaling therapy. Cancer Cells 3, 461-470 (1991).

5. Park, T.-K. et al. Total synthesis and proof of structure of a human breast tumor (globo-H) antigen. J. Am. Chem. Soc. 118 11488-11500 (1996).

6. Bilodeau, M. T. et al. Total synthesis of a human breast tumor associated antigen. J. Am. Chem. Soc. 117, 7840-7841 (1995)

Kim, I. J. et al. Defining the molecular recognition of globo $\mathrm{H}$ (human breast cancer) antigen through probe structures prepared by total synthesis. J. Org. Chem. 60, 7716-7717 (1995).

8. Ragupathi, G. et al. Immunization of mice with a fully synthetic globo $\mathrm{H}$ antigen results in antibodies against human cancer cells: a combined chemical-immunological approach to the fashioning of an anticancer vaccine. Angewandte Chemie 36, 125-128 (1997).

9. Nudelman, E., Levery, S. B., Kaizu, T. \& Hakomori, S.-I. Novel fucolipids of human adenocarcinoma: characterization of the major $\mathrm{Le}^{\mathrm{y}}$ antigen of human adenocarcinoma as trifucosylnanosyl $\mathrm{Le}^{\mathrm{y}}$ glycolipid (III ${ }^{3} \mathrm{FucV}^{3} \mathrm{FucVI}^{2} \mathrm{FucnLc}_{6}$ ). J. Biol. Chem. 261, 11247-11253 (1986).

10. Hummel, G. \& Schmidt, R. R. A versatile synthesis of the Lactoneo-series antigens-synthesis of sialy] dimer Lewis X and dimer Lewis Y. Tetrahedr. Lett. 38, 1173-1176 (1997).

11. Kaizu, T., Levery, S. B., Nudelman, E., Stenkamp, R. E. \& Hakomori, S.-I. Novel fucolipids of human adenocarcinoma: monoclonal antibody specific for trifucosyl $\mathrm{Le}^{y}\left(\mathrm{III}^{3} \mathrm{FucV}^{3} \mathrm{FuCVI}^{2} \mathrm{FucnLc}_{6}\right)$ and a possible three-dimensional epitope structure. J. Biol. Chem. 261, 11254-11258 (1986).

12. Kim, S. Y. Expression of $\mathrm{Le}^{\mathrm{y}}$ and extended $\mathrm{Le}^{\mathrm{y}}$ blood group-related antigens in human malignant, premalignant, and nonmalignant colonic tissues. Cancer Res. 46, 5985-5992 (1986).

13. Jeffrey, P. D. The X-ray structure of an anti-tumour antibody in complex with antigen. Nature Struct. Biol. 2, 466-471 (1995).
4. Helland, A.-C., Nilsson, M. \& Norberg, T. Synthesis of a trifucosyl Le ${ }^{y}$ heptasaccharide corresponding to a tumor-associated glycolipid. J. Carbohydr. Chem. 11, 77-88 (1992).

15. Wildmüller, R. \& Schmidt, R. R. Efficient synthesis of Lactoneo series antigens $\mathrm{H}$, Lewis X $\left(\mathrm{Le}^{\mathrm{x}}\right)$, and Lewis Y $\left(\right.$ Le $\left.^{y}\right)$ Tetrahedr. Lett. 35, 7927-7930 (1994).

16. Danishefsky, S. J. \& Bilodeau, M. T. Glycals in organic synthesis: the evolution of comprehensive strategies for the assembly of oligosaccharides and glycoconjugates of biological consequences. Angew. Chem. Int. Edn Engl. 35, 1380-1419 (1996).

17. Blackburne, I. D., Fredericks, P. F. \& Guthrie, R. D. Studies on unsaturated sugars with particular reference to the synthesis of 6-deoxy-6-fluoro derivatives. Aust. J. Chem. 29, 381-391 (1976).

18. Danishefsky, S. J. et al. Application of glycals to the synthesis of oligosaccharides: convergent total syntheses of the Lewis $\mathrm{X}$ trisaccharide sialyl Lewis $\mathrm{X}$ antigen determinant and higher congeners. J. Am. Chem. Soc. 117, 1940-1953 (1995).

19. Danishefsky, S. J., Behar, V., Randolph, J. T. \& Lloyd, K. O. Application of the glycal assembly method to the concise synthesis of neoglycoconjugates of $\mathrm{Le}^{\mathrm{y}}$ and $\mathrm{Le}^{\mathrm{b}}$ blood group determinants of $\mathrm{H}$-type I and H-type II oligosaccharides. J. Am. Chem. Soc. 117, 5701-5711 (1995).

20. Gervay, J., Peterson, J. M., Oliyama, T. \& Danishefsky, S. J. An unexpected sialylation: total syntheses of $\mathrm{G}_{\mathrm{M} 4}$ and a positional isomer. J. Org. Chem. 58, 5465-5468 (1993).

21. Griffith, D. A. \& Danishefsky, S. J. Sulfonamidoglycosylation of glycals. A route to oligosaccharides with 2-aminohexose subunits. J. Am. Chem. Soc. 112, 5811-5819 (1990).

22. Kameyama, A., Ishida, H., Kiso, M. \& Hasegawa, A. Synthetic studies on sialoglycoconjugates 22: total synthesis of tumor-associated ganglioside, sialyl Lewis X. J. Carbohydr. Chem. 10, 549-560 (1991).

23. Kondo, T., Tomoo, T., Abe, H., Isobe, M. \& Goto, T. Total synthesis of $\mathrm{GD}_{3}$, a ganglioside. Chem. Lett. 5, 337-338 (1996).

24. Danishefsky, S. J. et al. Remarkable regioselectivity in the chemical glycosylation of glycal acceptors: a concise solution to the synthesis of sialyl Lewis X glycal. J. Am. Chem. Soc. 114, 8329-8331 (1992).

25. Fügedi, P., Garegg, P. J., Lönn, H. \& Norberg, T. Thioglycosides as glycosylating agents in oligosaccharide synthesis. Glycoonjugate J. 4, 97-108 (1987).

26. Lönn, H. Glycosylation using a thioglycoside and trifluoromethanesulfonate. A new and efficient method for cis and trans glycoside formation. J. Carbohydr. Chem. 6, 301-306 (1987).

Acknowledgements. We thank G. Sukenick for NMR and mass spectral analyses and D. Live for NMR analyses. We also thank T.-K. Park for suggestions about the strategy of the synthesis. This work was supported by the National Institutes of Health.

Correspondence should be addressed to S.J.D.

\section{A major biopolymeric component to dissolved organic carbon in surface sea water}

\author{
Lihini I. Aluwihare ${ }^{\star}$, Daniel J. Repeta ${ }^{\star}$ \& Robert F. Chen \\ * Department of Marine Chemistry and Geochemistry, \\ Woods Hole Oceanographic Institution, Woods Hole Massachusetts 02543, USA \\ $\dagger$ Environmental and Coastal Oceans Sciences Program, University of \\ Massachusetts, Boston, 100 Morrissay Boulevard, Boston, \\ Massachusetts 02125-3393, USA
}

Organic carbon dissolved in sea water is an important component of the global carbon cycle ${ }^{1}$. Concentrations of dissolved organic carbon (DOC) in the ocean's surface mixed layer are at least twice those in the deep sea ${ }^{2,3}$, because of the production of soluble carbon compounds by marine algae in the euphotic zone $e^{4,5}$. But very little is known about the chemical composition of DOC, and the connection between photosynthetic production and DOC accumulation is not well understood ${ }^{6,7}$. Here we report the chemical characterization of macromolecular DOC at several sites in the Atlantic and Pacific oceans. Neutral sugars, acetate and lipids show similar distributions, suggesting that these constituents are linked together in a common macromolecular structure. Chemical linkage patterns between the oligosaccharide portions of dissolved organic matter subjected to ultrafiltration are highly specific, with little variation between ocean basins. We show that laboratory culture experiments on the decomposition of algal exudate produce macromolecular organic matter with similar compositions and linkage characteristics. We propose that a significant fraction of DOC in sea surface water consists of structurally related and biosynthetically derived acyl oligosaccharides that persist after more labile organic matter has been degraded.

Between $25 \%$ and $35 \%$ of marine DOC is in a high-molecularweight fraction that can be recovered by ultrafiltration or dialysis ${ }^{8-10}$. 